\title{
Medical Waste Treatment Technologies for Energy, Fuels, and Materials Production: A Review
}

\author{
Georgios Giakoumakis, Dorothea Politi and Dimitrios Sidiras *(D)
}

Citation: Giakoumakis, G.; Politi, D. Sidiras, D. Medical Waste Treatment Technologies for Energy, Fuels, and Materials Production: A Review. Energies 2021, 14, 8065. https:// doi.org/10.3390/en14238065

Academic Editor: Dino Musmarra

Received: 31 October 2021

Accepted: 30 November 2021

Published: 2 December 2021

Publisher's Note: MDPI stays neutral with regard to jurisdictional claims in published maps and institutional affiliations.

Copyright: (c) 2021 by the authors. Licensee MDPI, Basel, Switzerland. This article is an open access article distributed under the terms and conditions of the Creative Commons Attribution (CC BY) license (https:/ / creativecommons.org/licenses/by/ $4.0 /)$.
Laboratory of Simulation of Industrial Processes, Department of Industrial Management and Technology, School of Maritime and Industrial Studies, University of Piraeus, 80 Karaoli \& Dimitriou, GR 18534 Piraeus, Greece; ggiakoum@unipi.gr (G.G.); doritapoliti@unipi.gr (D.P.)

* Correspondence: sidiras@unipi.gr; Tel.: +30-21-0-414-2360

\begin{abstract}
The importance of medical waste management has grown during the COVID-19 pandemic because of the increase in medical waste quantity and the significant dangers of these highly infected wastes for human health and the environment. This innovative review focuses on the possibility of materials, gas/liquid/solid fuels, thermal energy, and electric power production from medical waste fractions. Appropriate and promising treatment/disposal technologies, such as (i) acid hydrolysis, (ii) acid/enzymatic hydrolysis, (iii) anaerobic digestion, (vi) autoclaving, (v) enzymatic oxidation, (vi) hydrothermal carbonization/treatment, (vii) incineration/steam heat recovery system, (viii) pyrolysis/Rankine cycle, (ix) rotary kiln treatment, (x) microwave/steam sterilization, (xi) plasma gasification/melting, (xii) sulfonation, (xiii) batch reactor thermal cracking, and (xiv) torrefaction, were investigated. The medical waste generation data were collected according to numerous researchers from various countries, and divided into gross medical waste and hazardous medical waste. Moreover, the medical wastes were separated into categories and types according to the international literature and the medical waste fractions' percentages were estimated. The capability of the examined medical waste treatment technologies to produce energy, fuels, and materials, and eliminate the medical waste management problem, was very promising with regard to the near future.
\end{abstract}

Keywords: medical waste; energy; fuels; chemicals

\section{Introduction}

Medical waste (MW) consists of healthcare units' waste, medical laboratories' waste, and biomedical research centers' waste, and its inappropriate handling raises serious risks of disease transmission through exposure to infectious materials to the MW handlers, the health care personnel, the patients, and the public [1]. The need for MW management (MWM) has increased during the COVID-19 time mainly due to the increase in MW amount and because MW creates significant dangers for the environment and human health [2,3]. The COVID-19 pandemic increased medical and municipal waste generation, in many countries by 350-500\%, especially plastic waste in developing and developed countries, showing the greatest feature of final disposal in Finland with $75 \%$ recycling while lowest quality is in India where $90 \%$ is dumped [4]. Healthcare is a fast-developing industry due to the demand for more sophisticated/demanding medical treatments, resulting in an increasing need for MW treatment (MWT) and MW disposal (MWD) [5]. Since MW involves a significant quantity of hazardous substances, poor MWM might lead to serious environmental and human health risks [6]. Life cycle assessment (LCA) and circular economy (CE) applied in the biomedical sector can deal with the medical, pharmaceutical, and dental wastes, describe the ways of MWM, face the problem of dental waste; and propose ways of 'green circulation' of this waste [7].

A meta-analysis of MWM practices in 78 countries was conducted by Singh et al. [8], identifying impediments and challenges facing the integration of MWM in the CE concept, 
considering the statistical correlations with healthcare expenditure per capita of GDP (HCECGDP), human development index, life expectancy, and environmental performance index. Barely $38.9 \%$ of MW was separated for appropriate management, while no more than $41 \%$ of employees were well qualified for MWD. Capoor and Parida [9] investigated the problems from COVID-19 MW and national and international authorities' guidelines on MWM during the COVID-19 pandemic. According to all the guidelines, the COVID-19 MWM follows environmentally friendly principles/practices of MWM to work safely and control the infection. Separation at source of COVID-19 MW, understanding, and safety measures during the MW-cycle shows the way out of this crisis.

Chisholm et al. [10] studied the sustainability aspects of MWM in Africa as regards flexible solutions for environment protection and human health safety. They suggested policies and solutions associated with sustainability and MWM supporting decision-makers in developing sustainability strategies using environmentally friendly technologies for efficient MWT and MWD methods which link the healthcare system with the stakeholders/decisionmakers on evolving health procedures and programs.

Thorough planning, usage of considerable mobile reprocessing facilities, and established procedures for discarding of MW could decrease the danger of COVID-19 spread in developing countries [11]. Tirkolaee and Aydın [12] developed a sustainable MWM system for collection and transportation of MW in pandemics, they designed numerous various scales practical examples, solved the problem using CPLEX solver, and they compared diverse conditions. They also investigated the practical implications [13]. Moreover, He et al. [14] optimized the problem of the automated MW sorting system by taking into account the operational flow of MW. They developed a mixed-integer programming model for the optimization of the MW assignment, presorting stations, and automated guided vehicles.

The scope of the present review is to evaluate the existing MW treatment/disposal technologies such as (i) acid hydrolysis, (ii) acid/enzymatic hydrolysis, (iii) anaerobic digestion, (vi) autoclaving, (v) enzymatic oxidation, (vi) hydrothermal carbonization/treatment, (vii) incineration/steam heat recovery system, (viii) pyrolysis/Rankine cycle, (ix) rotary kiln treatment, (x) microwave/steam sterilization, (xi) plasma gasification/melting, (xii) sulfonation, (xiii) batch reactor thermal cracking, and (xiv) torrefaction, as regards their capability to produce energy, fuels, and materials.

\section{Medical Waste Generation and Classification}

\subsection{Medical Waste Generation}

According to Song et al. [15], COVID-19 threatens human health and produces a large amount of MW dangerous for the environment. In the Hubei Province, during COVID19 , a calculation was made of the MW production (MWP) rate using a neural network model, related to the environmental impact, resulting in four scenarios for the estimation of the environmental impact of new MW generated during the pandemic with a volume of approximately 3367 tons. Kalantary et al. [16] estimated that the COVID-19 pandemic increased MW generation (MWG) by 102\% in private and public hospitals in Iran. Moreover, the fraction of infectious waste increased by $9 \%$ in MW composition and $121 \%$ compared to pre COVID-19 situation. Maalouf and Maalouf [17] analyzed the infectious MWG rates (MWGRs) and MWM practices in Lebanon during the COVID-19 pandemic, estimating 39 tons per month, COVID-19-related infectious MWG, i.e., 5-20\% of total infectious MW. Mekonnen et al. [18] assessed the MWG in Ethiopia during the COVID-19 pandemic and estimated about $493 \mathrm{~kg}$ /day MWGR in all hospital service units. A total of $62 \%$ of the total MW production was general waste (GW) and 38\% was hazardous medical waste (HMW). In Peshawar, Pakistan, Khalid et al. [19] studied the MWM procedures in teaching hospitals and found that government teaching hospitals produced $900 \mathrm{~kg} /$ day MW, government non-teaching hospitals $167 \mathrm{~kg}$ /day and private teaching hospitals $79 \mathrm{~kg} /$ day without any separation at generation point. In Vietnam, Nguyen et al. [20] estimated the MWGR and MW composition during the COVID-19 pandemic considering the resources/equipment supply and found 1486 tons of MW per year produced from the isolated COVID-19 patients' 
treatment, quarantine in healthcare establishments, and centralized quarantine $(4.6,3.9$, and $46.4 \mathrm{~g} / \mathrm{bed} /$ day, respectively), vaccination (10.5 g/shot), and testing ( $50 \mathrm{~g} /$ test), where plastic was 76.7\%. Tsai [21] in Taiwan analyzed the MWG and the impact of COVID-19 on MWGR and quantity which increased from 35,747 tons in 2016 to 40,407 tons in 2019, i.e., increase by $4.17 \%$. The infectious MW was $89 \%$ of the total MW, i.e., an increase of $4.14 \%$.

In Dar es Salaam city, Tanzania, Anicetus et al. [22], estimated the quantity of MWG in 4 healthcare units and found the generation rate per healthcare ranging from $299 \mathrm{~kg} / \mathrm{day}$ to $1554 \mathrm{~kg} /$ day. According to Borowy [23], health facilities have an increasing MWGR, while $15 \%$ of MW is infectious, radioactive, or toxic. Khan et al. [6] mentioned the significant fluctuation in the MWG from various regions. In Bench Maji Zone, Ethiopia, Meleko et al. [24] assessed the MWGR in different health facilities and found that MWs were sharps, infectious, pathological, and pharmaceutical, and the MWGR was 0.267 (23.3\%), 0.2695 $(23.6 \%), 0.441(38.6 \%)$ and $0.166(14.5 \%) \mathrm{kg} /$ day, respectively. Minoglou et al. [25] examined the influence of several socioeconomic and environmental parameters on the MWGR. They found correlations between the quantities of $\mathrm{MW}$, in $\mathrm{kg} / \mathrm{bed} / \mathrm{day}$, versus economic indices such as HCECGDP, social indices such as the Human Development Index, mean years of schooling, life expectancy, under-five mortality rates, HIV prevalence, deaths due to tuberculosis and malaria, and total $\mathrm{CO}_{2}$ emissions as environmental sustainability index, from 42 countries. Maamari et al. [26], analyzed infectious MWGRs and patterns in Lebanon for 5 years for 57 out of a total of 163 hospitals in the country. They reported that the large private hospitals showed a high MWGR of $2.45 \mathrm{~kg} / \mathrm{bed} /$ day, while the other categories showed $0.94 \mathrm{~kg} / \mathrm{bed} /$ day. Moreover, infectious MWG was $1.42 \mathrm{~kg} /$ capita/year. Debere et al. [27], reported for Addis Ababa, Ethiopia, year 2011, MWG 0.361-0.669 kg/patient/day, consist of 58.7\% non-HMW and 41.3\% HMW. Public hospitals generated $59.2 \%$ of total MW in comparison to $40.5 \%$ of private hospitals.

In Greece, Komilis et al. [28], calculated the hazardous MWGRs, based on 132 healthcare facilities data, especially in Athens, for a period of 22 months, i.e., the years 2009-2010. These facilities were public and private, categorized into general, birth, pediatric, cancer treatment, military, psychiatric and university hospitals. The MWGR for the public psychiatric hospitals and the public university hospitals was 0.012 and $0.72 \mathrm{~kg} / \mathrm{bed} / \mathrm{d}$, respectively. Moreover, MWGR for the psychiatric clinics, and the birth clinics was 0.0012 and $0.49 \mathrm{~kg} / \mathrm{bed} / \mathrm{d}$, respectively, considering the private healthcare facilities. In Athens, the public and private health care facilities concern general, birth, pediatric, cancer, psychiatric military, and university hospitals [29,30].

Hamoda et al. [31], studied the HMW and non-HMW MWGRs for two large public hospitals in Kuwait and correlated to the number of patients, the beds' number, and the conducted activity type in different hospitals sections. The MWGR was sufficiently corelated with the number of patients and not with the beds number. The MWGRs were 4.89-5.4 kg/patient/day, and 3.65-3.97 kg/bed/day. In Sivas, Turkey, Altin et al. [32] evaluated the physical and elemental composition of MW in four hospitals and estimated that the daily MWGR was $985 \mathrm{~kg} /$ day. Additionally, the moisture content was $14.2 \%$ and the MW was $92 \%$ combustible MW and $8 \%$ noncombustible MW. The combustible MW was $41.2 \%$ plastics, $16 \%$ paper, $4 \%$ cardboard, $10.2 \%$ textiles, and $17 \%$ food waste.

The MWG data are given in Table 1 for various countries according to numerous researchers, divided in total MW and HMW. 
Table 1. Medical waste generation data.

\begin{tabular}{|c|c|c|c|}
\hline Country & $\begin{array}{c}\text { Total Medical Waste } \\
\text { (Kg/Bed/Day) }\end{array}$ & $\begin{array}{l}\text { Hazardous Medical Waste } \\
\text { (Kg/Bed/Day) }\end{array}$ & References \\
\hline Algeria & 1.0 & & [8] \\
\hline Belgium & 1.4 & & [33] \\
\hline Brazil & 4.4 & 2.3 & [34] \\
\hline Bolivia & 0.5 & & [8] \\
\hline Bulgaria & 2.0 & & [8] \\
\hline Canada & 8.2 & & [35] \\
\hline China & 0.6 & & [8] \\
\hline Ecuador & 0.4 & & [8] \\
\hline Egypt & 1.2 & & [8] \\
\hline Ethiopia & 1.1 & 0.6 & [36] \\
\hline Ethiopia & 6.03 & & [37] \\
\hline France & 3.3 & & [8] \\
\hline Germany & 3.6 & 1.4 & [38] \\
\hline Greece & & $0.26-0.89$ & [39] \\
\hline Greece & 1.4 & & [40] \\
\hline Greece & 1.5 & & [41] \\
\hline Greece & & 0.33 & [29] \\
\hline Greece & & 0.4 & [30] \\
\hline India & 0.5 & & [41] \\
\hline Iran & 3.5 & 1.039 & [42] \\
\hline Ireland & 7.7 & & [43] \\
\hline Italy & 1.0 & & [33] \\
\hline Japan & 2.3 & & [8] \\
\hline Kazakhstan & 5.34 & 1.2 & [44] \\
\hline Kuwait & 3.8 & & [31] \\
\hline Latvia & 1.18 & & [45] \\
\hline Lebanon & 2.45 & 0.95 & [26] \\
\hline Libya & 1.3 & & [46] \\
\hline Netherlands & 1.7 & 0.7 & [38] \\
\hline Nigeria & 2.5 & & [8] \\
\hline Norway & 3.9 & & [8] \\
\hline Pakistan & 2.2 & & [47] \\
\hline Pakistan & 2 & & [48] \\
\hline Palestine & 1.57 & 0.78 & [49] \\
\hline Portugal & 1.5 & & [33] \\
\hline Serbia & 1.9 & & [8] \\
\hline Spain & 4.4 & & [50] \\
\hline Taiwan & 1.9 & & [8] \\
\hline UK & 3.3 & & [50] \\
\hline USA & 8.4 & & [8] \\
\hline Vietnam & 1.57 & 0.14 & [51] \\
\hline Yemen & 2.41 & 0.63 & [52] \\
\hline
\end{tabular}

\subsection{Medical Waste Classification}

The types of MW or healthcare waste according to the World Health Organization (WHO) [53] are: (i) Infectious MW (blood/bodily fluids/cultures/infectious agents/autopsi es/infected animals/swabs/bandages/medical devices), (ii) Pathological MW (human tissues/organs/fluids/body parts/animal carcasses), Sharps MW (syringes/needles/disposa ble scalpels/blades), (iii) Chemical MW (solvents/reagents/disinfectants/sterilant/heavy metals/mercury/batteries), (iv) Pharmaceutical MW (drugs/vaccines), (v) Cytotoxic MW (genotoxic/highly HMW/mutagenic/teratogenic/carcinogenic/cancer treatment cytotoxic drugs/metabolites), (vi) Radioactive MW (radionuclides/radioactive diagnostic and radiotherapeutic materials), and (vii) non-HMW or general MW (waste with no physi$\mathrm{cal} /$ chemical/biological/radioactive hazard).

In the United States, the Environmental Protection Agency (EPA) [45], defines the following solid MW categories: (i) HMW (not infectious but dangerous, e.g., chemical 
waste, discarded equipment and sharps), (ii) General Waste (bulk of office waste, mostly typical household, and most MW), (iii) Radioactive Waste (waste generated by radioactive treatments, from medical equipment for nuclear elements and from cancer therapies) and (iv) Infectious Waste (waste that could lead to an infection in humans, anything related to bodily fluids and blood).

According to Das et al. [1], MW can be categorized as (i) hazardous, (ii) nonhazardous, and (iii) other waste. The hazardous fraction can be classified into (a) chemical, (b) infectious, (c) pathological, (d) radioactive, (e) sharps, and (f) pharmaceutical.

According to Korkut [54] the UK government has promoted the differentiation of MW into the following categories: (i) Domestic/Municipal (concerns the other general nonMW, (ii) Offensive Waste (concerns all non-infectious and especially nappy and sanitary waste), (iii) Anatomical Waste (all waste from an animal or human including in this way organs, blood bags, and body parts), (iv) Cytotoxic/Cytostatic Waste (drugs and medicines with cytotoxic/cytostatic character, or items related to toxic or carcinogenic medicine), (v) Medicinal Waste (creams, pills, and medicine, that are not cytotoxic/cytostatic), and (vi) Infectious Waste (contaminated with infectious bodily fluids from individuals treatment).

According to Eker and Bilgili [55], the Western world including the USA and most European countries adopts a classification model that separates medical waste as follows: radioactive, hazardous, infectious, general. According to Windfeld and Brooks [50], MW mainly consists of radioactive, infectious, and toxic materials that are associated with environmental pollution and health risks unless they are properly managed, treated and finally disposed of. Johannessen [56] reports that laboratories, research facilities, and healthcare establishments waste is MW. According to Kagonji and Manyele [57], various classifications of MW have been proposed so far, with the most accepted one being that the main component of MW is hazardous and non-hazardous fractions. When reporting MWGR, emphasis is given to the effort to identify if the non-HMW stream is included, because this fraction, in many cases, represents $80 \%$ of the overall MW stream.

Various factors that contribute to the presence of the significant variability of the reported MWGR, such as the presence of different hospital facilities, doubt if the nonHMW fraction can be presented in the MWGR quantification, financial factors, or even the units of expressing MWGR further complicate the comparison of MWGR among countries with different financial status and different legislation. As an example, Minoglou et al. [25] report that the following parameters are implicated in the gross differences noticed among countries: illegal dumping, MW management systems, differences in the operation of healthcare services, and different legal frameworks.

According to the recent literature, $\mathrm{MW}$ is classified according to materials use and the waste disposal practices [25]. According to Reinhardt and Gordon [58], infectious waste, which is suspected in many cases to contain a sufficient concentration of pathogens that cause sickness in vulnerable hosts, constitutes another class that contains various materials or instruments that have been related to infected people or animals, infected animals essentially from laboratories, MW that has been related to infected patients, in many cases undergoing hemodialysis, infected patients MW in isolation districts, MW from autopsies and surgery on patients with the presence of infectious diseases, and stocks and cultures of infectious agents from laboratory work.

According to Thakur and Anbanandam [59], various interchangeable terms depending on every country's legislation have been proposed for the same kind of MW. A common assumption in the literature is that MW can be considered as any MW that is produced as a byproduct of healthcare activity at laboratories, hospitals, dentists, and doctor's surgeries.

At the global level, a constant international growth in MWG is observed. In lowincome countries, MWG, although lower than in the developed countries, is sharply increasing because of the enhanced access to healthcare facilities. In rich countries, the increase in MWGR is assigned to the ageing population, leading in this way to an increasing health care waste volume [57]. 
Liberti et al. [60] reported that MWG by healthcare facilities concerns used syringes and needles, radioactive materials, medical devices, pharmaceuticals, chemicals, blood and body fluids, diagnostic samples, body parts, and soiled dressings. Rehabilitation services account for $52 \%$ of total infectious MWG, analytical laboratories account for $23 \%$, and surgeries (14\%), dialysis units $(7 \%)$ and first aid account for the remaining $4 \%$. The false management of health care waste potentially exposes risks of toxic injuries to the environment and affects not only patients but also the community as well as waste handlers and health care workers.

Table 2 was constructed considering the categorization of MW in the international literature, indicating the numerous differences between the approaches of the various researchers. In Figure 1 is shown an explanatory schematic diagram on medical waste categories/types, considering all these opinions. The various medical waste fraction is presented in Table 3 as percentages. In Figure 2 are presented the average values, the upper limits, and the lower limits of the main medical waste fractions percentages.

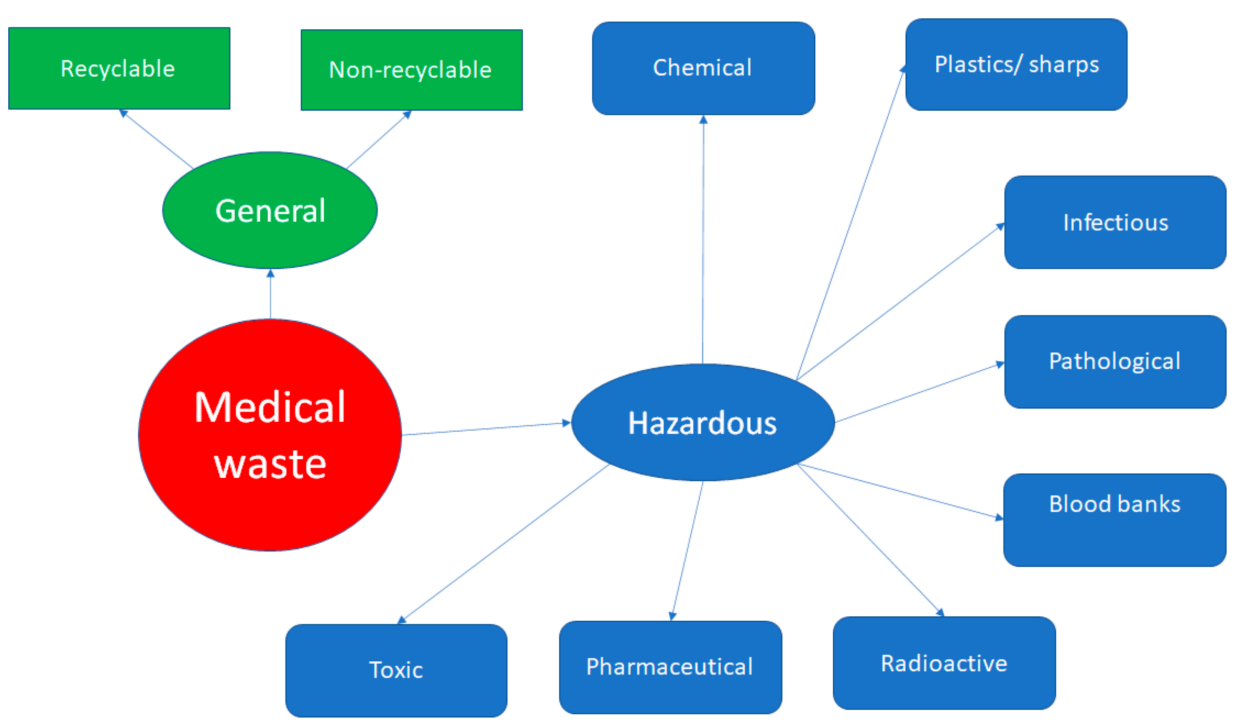

Figure 1. A schematic diagram on medical waste categories/types.

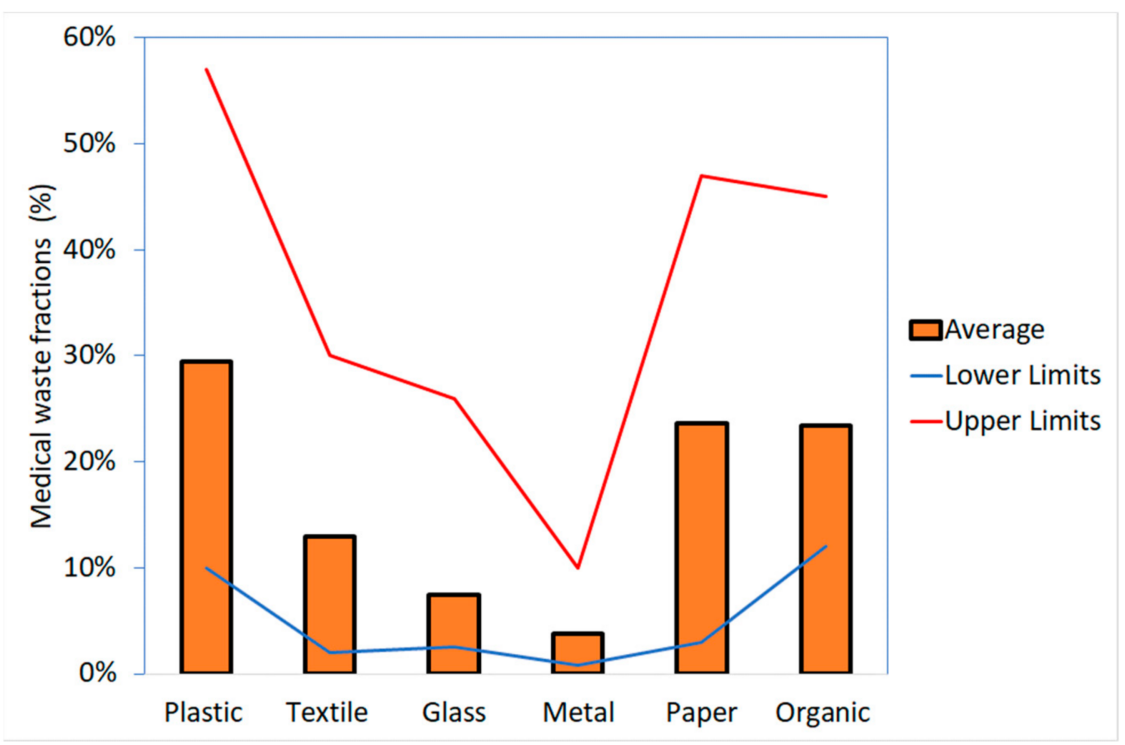

Figure 2. Average values, upper limits, and lower limits of the main medical waste fractions. 
Table 2. Medical waste categories/types.

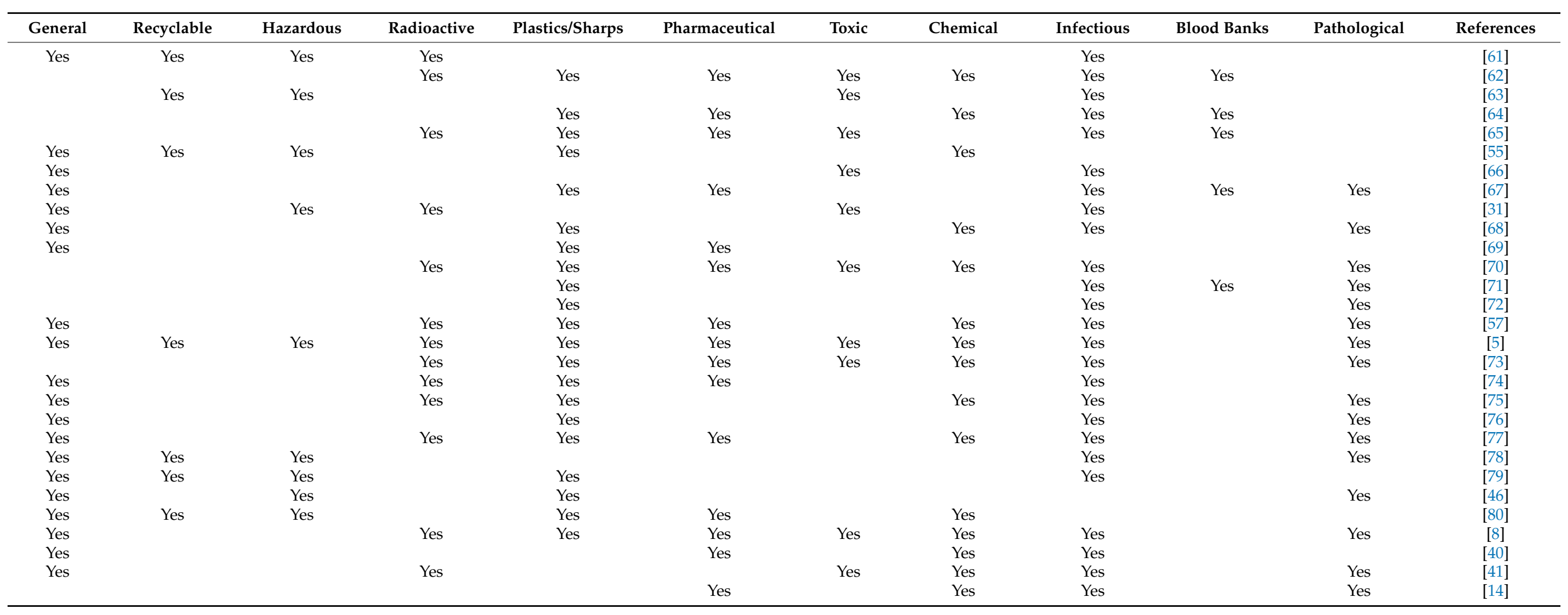


Table 3. Medical waste fractions' percentages.

\begin{tabular}{|c|c|c|c|c|c|c|c|c|c|c|}
\hline Country & Source & Source No & General & Plastic & Textile & Glass & Metal & Paper & Organic & References \\
\hline Canada & NA & & & $14 \%$ & & $3 \%$ & $2 \%$ & $45 \%$ & $17 \%$ & [81] \\
\hline China & MSWAC & 1 & & $45 \%$ & $30 \%$ & $2.50 \%$ & $2.50 \%$ & $10 \%$ & & [82] \\
\hline China & NA & - & $56 \%$ & $36 \%$ & & $4 \%$ & $4 \%$ & & & [8] \\
\hline Egypt & $\mathrm{H}$ & 8 & & $19 \%$ & $17 \%$ & $9 \%$ & $1 \%$ & $24 \%$ & $28 \%$ & [83] \\
\hline Greece & $\mathrm{H}$ & 29 & & $18 \%$ & & $8 \%$ & $9 \%$ & $47 \%$ & $16 \%$ & [40] \\
\hline Greece & $\mathrm{HF}$ & 1 & $82 \%$ & & & $4 \%$ & $6 \%$ & & & [66] \\
\hline India & $\mathrm{GH} / \mathrm{AH}$ & $2 / 1$ & $54 \%$ & $10 \%$ & $15 \%$ & $4 \%$ & $1 \%$ & $15 \%$ & & [84] \\
\hline Iran & $\mathrm{EH}$ & 12 & & $29 \%$ & $16 \%$ & $8 \%$ & $2 \%$ & $14 \%$ & $31 \%$ & [85] \\
\hline Iran & $\mathrm{EH} / \mathrm{UH} / \mathrm{MH} / \mathrm{PH} / \mathrm{GoH}$ & 10 & & $23 \%$ & $11 \%$ & $4 \%$ & $1 \%$ & $13 \%$ & $31 \%$ & [43] \\
\hline Iran & $\mathrm{H}$ & 3 & & $30 \%$ & $14 \%$ & $4 \%$ & $1 \%$ & $19 \%$ & $18 \%$ & [86] \\
\hline Iran & $\mathrm{H}$ & 14 & & $41 \%$ & $17 \%$ & $4 \%$ & $5 \%$ & $8 \%$ & $21 \%$ & [87] \\
\hline Italy & NA & & & $47 \%$ & & $7 \%$ & $2 \%$ & $33 \%$ & & [88] \\
\hline Jordan & $\mathrm{H}$ & 21 & & $27 \%$ & $11 \%$ & $10 \%$ & $5 \%$ & $38 \%$ & & [89] \\
\hline Korea & $\mathrm{HF}$ & 478 & & $47 \%$ & & & $6 \%$ & $37 \%$ & & [72] \\
\hline Kuwait & $\mathrm{PH}$ & 2 & & $18 \%$ & $11 \%$ & $10 \%$ & $9 \%$ & $32 \%$ & $12 \%$ & [31] \\
\hline Libya & $\mathrm{UH} / \mathrm{PC} / \mathrm{HC} / \mathrm{PrH} / \mathrm{GH}$ & $2 / 2 / 2 / 4$ & & $24 \%$ & $9 \%$ & $8 \%$ & $1 \%$ & $20 \%$ & $38 \%$ & [46] \\
\hline Mauritius & $\mathrm{NH} / \mathrm{GH} / \mathrm{PrC}$ & $1 / 1 / 1$ & & $24 \%$ & $8 \%$ & $3 \%$ & & $24.00 \%$ & $13 \%$ & [90] \\
\hline Pakistan & $\mathrm{CH}$ & 1 & & $57 \%$ & & $11.00 \%$ & & $3.00 \%$ & & [42] \\
\hline Palestine & $\mathrm{GH}$ & 3 & & $30 \%$ & $2 \%$ & $8 \%$ & $2 \%$ & $33 \%$ & $25 \%$ & [49] \\
\hline Taiwan & UH & 1 & & $50 \%$ & $10 \%$ & & & $16 \%$ & $22 \%$ & [76] \\
\hline Turkey & $\mathrm{GH} / \mathrm{MH}$ & $3 / 1$ & $3 \%$ & $41 \%$ & $10.20 \%$ & $7.20 \%$ & $0.80 \%$ & $20.70 \%$ & $17.10 \%$ & [32] \\
\hline UK & $\mathrm{H}$ & & & $21 \%$ & & & $2 \%$ & $47 \%$ & $14 \%$ & [33] \\
\hline USA & NA & & & $15 \%$ & & $7 \%$ & $10 \%$ & $45 \%$ & $10 \%$ & [91] \\
\hline Yemen & $\mathrm{GH}$ & 4 & & $22 \%$ & & $11 \%$ & $10 \%$ & $22 \%$ & $27 \%$ & [52] \\
\hline
\end{tabular}

$\mathrm{EH}=$ educational hospital, $\mathrm{GH}=$ general hospital, $\mathrm{AH}=$ anticancer hospital, MSWAC = medical solid waste average composition, $\mathrm{HF}=$ healthcare facilities, $\mathrm{MH}=$ maternity hospital, $\mathrm{CH}=$ children's hospital, $\mathrm{PH}=$ public hospital, $\mathrm{PC}=$ private clinic, $\mathrm{PrH}=$ private hospital, $\mathrm{HC}=$ health center, $\mathrm{NH}=$ national hospital, $\mathrm{NA}=$ not available, $\mathrm{UH}=$ university hospital, $\mathrm{M} . \mathrm{H} .=\mathrm{military}$ hospital, GoH $=$ governmental hospital.

\section{Medical Waste Treatment Technologies}

\subsection{Medical Waste Handling}

According to Liu et al. [92], MWM is significant for the medical practitioners who handle various MW treatment technologies (MWTTs), such as incineration, chemical disinfection, microwave, autoclaving and reverse polymerization. These MWTT need to consider health hazards, social acceptance, environmental impact, and economical cost. To select the most suitable technology, a multi-criteria decision-making (MCDM) framework is needed, involving several factors. Consequently, a new Pythagorean fuzzy-based decisionmaking methodology was developed to provide a fuzzy combined solution framework to rank the alternatives.

According to Zhao et al. [93], MW has increased due to the COVID-19 pandemic and has stimulated high interest in MW treatment/disposal. Additionally, the recovery of MW energy is mandatory in order to achieve higher heating value (HHV). The use of sustainable, economical, and environmentally friendly MWTTs, achieving higher energy recovery, is essential for the harmless disposal of MW.

Kenny and Priyadarshini [5] examined the current MW disposal methods and their environmental and public health effects, finding that MWTTs have a high dependence on basic, low-tech MWTTs while there is lack of use of 'greener' MWTTs due to cost, access, and feasibility. Moreover, MWTTs depends on the development level of the country. Bucătaru et al. [94], found a correlation between the different forms of MWM in different countries, which effects the processes for the collection, storage, and destruction of the HMW. Letho et al. [95], found that understanding and practice of MWM by the healthcare workers decreases the lack of proper application of the National guidelines.

The main target of healthcare facilities is to decrease health associated problems caused by improper MWM as well as to prevent these potential consequences for the health of the community. Healthcare services create waste with a higher potential for injury and infection than any other form of waste. MWM is presented as an integral part of healthcare 
services, since inadequate MWM can be harmful and thus counteract the benefits offered by these services [96].

MWM has provoked an intense scientific dialogue on MWG because of the healthcare activities of which the inappropriate management affects animals and plants, the community, and the environment. This concern is growing based on the development of healthcare facilities number, as population growth reduces, in many cases, the space for MWD. Moreover, MWG by changes in human behaviors related to lifestyle, such as the increasing use of disposables, threatens natural resources and human beings. In addition, exposure because of environmental contamination by laboratory and pharmaceutical waste leads to disease in animals and humans [74]. Additionally, MW may have a long-term effect on human health, through underground water sources polluted by untreated MW either buried in the ground or drained in the domestic sewer system. Many researchers emphasize that many individuals can be infected either through infected people or MW or through affected animals, surface water or air, ground water, or contamination of soil [97].

Low-income countries usually apply poor MWM policies, because of very limited resources. Therefore, in these countries, MW is disposed of and handled as domestic waste, posing a significant threat to the waste workers' health, the public health and the environment [96]. Scarce data are currently available regarding a commonly accepted system for effective hospital waste management, especially in rural or privately funded hospitals in poorer countries. However, the waste generation rate in private and public hospitals in Kampala, Uganda, varies substantially based on patients' condition, giving emphasis to items carried into the ward, visitors number, and type or state of condition [74].

The WHO has emphasized the significance of acting with discretion on hospital waste handling. In an assessment conducted in 22 different developing nations and based on the outcome, it was found that $18-64 \%$ of the healthcare units included in the study did not use proper waste management practices. Mentzelou et al. [78] reported that the most essential factors that are underestimated or neglected during the process of MWM in Greece are: assessing the required activation, human resource training, and use of proper waste collection and, in many cases, disposal of raw collection materials. The main characteristics that determine waste handling are (i) benefits and profits from shelling and recycling as well as zero incidents, (ii) cost of transportation, storage, and the process of deposit, (iii) locations and nature for waste recycling, disposal, and storage, (iv) name and registered places of companies of the recycling and disposal firms, (iv) human resource activities, (v) date of transport, (vi) origin and nature of the waste, and (vii) weight. The lack of standardized and commonly accepted guidelines for MWM in both developed and underdeveloped countries as well as the poor data in the literature create the need for greater awareness and collaboration among research centers and authorities. The fact that only a few researchers have studied the subject of MW creates the need for greater awareness.

\subsection{Medical Waste Collection, Separation and Transportation}

Govindan et al. [98] developed a bi-objective mixed-integer linear programming software for MWM during the COVID-19 outbreak by simultaneously minimizing the total costs and risks of exposure of the population to contamination. They included the locationrouting problem, the vehicle scheduling/failure, the time window-based green vehicle routing problem, the split delivery, the people risk, and the load-dependent consumption of the fuel to process both infectious and non-infectious MW.

Healthcare facilities and hospitals usually provide laboratories, clinics, and surgery with color-coded bins or bags for collection and disposition of waste. Different colors (usually yellow, red, or green) denote different waste stream or types of waste. Unfortunately, no global or even local coloring system has been imposed by international or national health authorities, so that others rely on the MW source for sorting, and others use pathogenicity risk to determine the MWD stream [99]. Lack of standardization results in ineffective MW sorting so that healthcare workers may mistakenly dispose of objects in the infectious MW stream and cause unnecessary infectious MWG [100]. It is well established 
that most of the hospital MWG is noninfectious and could thus be treated as usual household waste in either rubbish dumps or recycling programs [101]. Improper MW sorting has considerable consequences, as there is a substantial cost premium to dispose of infectious waste. United States' authorities have estimated that the cost of disposing of infectious waste is much higher when compared to the cost of disposing of typical non-infectious waste (USD $0.79 / \mathrm{kg}$ vs. USD $0.12 / \mathrm{kg}$ ) [75]. Additional data from the UK confirms that the cost of disposing of typical infectious waste is comparable to that reported in the USA (GBP 0.45/kg). Disposal of MW must also be completed in a way that ensures minimal or ideally zero accidental exposure of workers responsible for handling such infectious items. Healthcare facilities are legally responsible for ensuring that their personnel do not touch the infectious MW placed in the appropriate waste bin. However, even in countries with strict legal frameworks such as the UK, there are reports suggesting that not only the guidelines do not provide sufficient precautions to avoid contact with HMW, but also safe practices are often ignored [102]. The legislative incompetence regarding poor MWM practices may result in infection and disease of either patients or workers, and thus legal liability for the hospital administration. EPA has concluded that the potential of MW causing disease is greater at the creation point. This finding further imposes the need for developing safeguards in healthcare facilities. According to the EPA suggestions, "safeguarding of infectious medical waste within healthcare facilities ought to be made a top waste management priority" [45].

Tirkolaee and Aydin [12] applied an MWM model for collection and transportation, by (i) using heuristic and meta-heuristic algorithms, (ii) considering 'planning cycles', (iii) applying uncertainty and forecasting techniques such as robust optimization, and (iv) integrating emerging technologies.

Medical waste is usually transported from the place it is produced to the treatment site that is located either within the healthcare facility or in a central offsite establishment. The most frequently used methods of treatment are incineration, autoclaving, and microwaving, which result in the residual ash. This final product is usually transported to the landfill for disposal [103] by a contractor who has the responsibility of the final disposition at the appropriate waste depot [104]. This third part collects the waste from central points and transports it safely to the final disposal facility. Unfortunately, there are several drawbacks to this procedure since there are legal gaps concerning the responsibilities of the contractors, who can earn a lot of money by skipping the legislation and inappropriately disposing of medical waste. The cost of disposal has been estimated at GBP 450/ton in the UK and USD $790 /$ ton in the USA $[75,102]$ so the third-party firms have a strong incentive to dispose of medical waste with minimal or no treatment in less expensive ways and not to follow the guidelines for proper transport to the final treatment facility for sterilization. A rigid medical waste tracking system is a prerequisite to avoid or at least minimize illegal dumping, which can otherwise become chronic and result in increased risk for public health and the environment because of pathogen release [104]. Weak legislation can also provide third parties with another possibility of pocketing money; they can resell items that should be disposed of, e.g., sharps on the black market for re-use. Recovered and non-sterile sharps represent significant risk for patients' infection via spread of blood-borne pathogens [105]. Reusing or recycling of potentially infectious MW is not allowed regardless of the use of a sterilization process [82].

\subsection{Treatment and Disposal Technologies for Medical Waste}

The quantity of used personal protective equipment, e.g., facemasks, gloves, etc., and the spread of infectious MW from hospitals, healthcare facilities, and quarantined households increased due to the COVID-19 pandemic. Moreover, food and plastic waste increased. As a result, MWT facilities became overburdened, necessitating the use of alternative handling and dumping such as co-disposal of MW in general solid waste incinerator, industrial ovens, cement kilns, and deep garbage dump, to increase handling capability. Consequently, the operation of such facilities must be upgraded for MW handling according 
to the limitations as regards COVID-19 [106]. Appropriate MWM practices improve landfill operations and prevent the spread of COVID-19, while on-site treatment and temporary storage helps to reduce the MWM problem [1]. The WHO official statement that today there are nearly no green, affordable options for secure disposal of contagious wastes [53], reflects the major concern of the international community regarding the safety of disposal at a reasonable cost and with minimal environmental burden [104]. The proper collection mechanisms for infectious MW using trained workers and specific containers, and in situ pretreatment is necessary [107]. In the Western world, $50 \%$ of $\mathrm{MW}$ is incinerated, $30 \%$ is autoclaved, and the rest is treated by alternative processes [82,108]. Incineration raises several concerns regarding air pollution and formation of toxic polychlorinated dibenzo-p dioxins (dioxins) and polychlorinated dibenzofurans (furans) following combustion [75] The need for alternative treatment methods that safely kill any pathogens is unquestionable and has resulted in the use of autoclaving and microwaving, among others.

\subsection{Sanitary Landfill Technology}

Ozbay et al. [109] investigated landfills' damaging effects on the environment and public health and the necessity for appropriate MWM practices to eliminate these effects. Insufficient landfill management causes problems regarding leachate collection and landfill gas generation, resulting in increased groundwater and air pollution. These drawbacks of using landfills as the major disposal technique lead to the effects of improper landfill management on the environment and human health. According to Hereher et al. [110], the most appropriate way to utilize the disposal of solid MW is landfilling in developing countries. Siting the possible location for landfills signifies one of the most popular functions of Geographic Information Systems (GIS). They applied this methodology to find suitable locations for landfills in Muscat Governorate, Oman. Moreover, Nik Ab Rahim et al. [111] reported that extensive non-engineered landfilling procedures in developing countries have increased environmental matters, while using a sanitary landfill seems unfeasible because of economic powerlessness. In Peninsular Malaysia, they investigated the viability of a sanitary landfill plan by incorporating its environmental issues into the plan assessment while at the same time using three policy-related procedures. Kareem et al. [112] studied a landfill where MWD is a complex problem associated with several aspects and guidelines. They found that the best sanitary landfill site in the case of An-Najaf city was defined by applying a GIS using eight suitable criteria, i.e., urban area, roads, soil types, rivers, elevation, wind, slope, and religious/archaeological/historical places.

The sanitary landfill procedure is the oldest method for MWD that is still used in several low-income countries. It is based on the decomposition of waste into harmless substances through long-term storage in the landfill's ground. Unfortunately, this way of disposal is accompanied by the infiltration of various toxic substances such as pathogens and radioactive materials so that these substances will seriously affect the environment and humans. An effective way of overcoming this issue is to select the sanitary landfill and to ensure that the anti-seepage system is covered with a layer of clay, high-density polyethylene, and other materials as well as with the appropriate landfill gas collection system and output pipelines. Moreover, local authorities must take into consideration the nature of the medical waste, the geological conditions, the climate, and the distance from the nearest civil landscape to license the construction of such facilities. The sanitary landfill method is cheap, easy to install, but there are several limitations to its use, such as the need for disinfection and reduction in the waste before landfilling, the necessity to inhabit a large terrestrial area, and the production of lots of harmful gases as well as the production of $\mathrm{O}_{2}$ and $\mathrm{H}_{2}$. In addition, periodic and long-term monitoring of soil and groundwater is required $[83,113]$.

\subsection{High Temperature Incineration Technology}

Ilyas et al. [114] investigated numerous disinfection technologies for COVID-19 MW handling, separation, and collection, following several physical and chemical treatment 
stages. Additionally, policy guidelines on the international initiatives for COVID-19 MWM with the use of various disinfection processes were examined and some examples were successfully applied to decrease health and environmental consequences.

Incineration of medical waste is a universal method of disposition for all kinds of waste that is suitable for all kinds of infectious waste. Incineration employs a high-temperature combustion range $\left(800-1200^{\circ} \mathrm{C}\right)$, which completely kills the pathogen while also burning $90 \%$ of the organics $[115,116]$. Moreover, deep oxidation of the waste under hightemperature flame results in the drying and incineration of the substances and their conversion into a residue mass that can be treated as a harmless material and gas. The application of this method is effective since the waste mainly consists of hydrocarbons with a high calorific value that can be easily destroyed during incineration [50].

There are some restrictions in the use of this approach such as the requirement for constant high furnace temperature, high oxygen mixing, appropriate turbulence and mixing degree of the equipment, maintenance of moisture content, sufficient gas residence time, periodical maintenance of the equipment, and finally, sufficient gas residence time and control of the final flue gas. The volume and weight of the final product are significantly reduced, the waste is destroyed, the method can be effectively applied to all types of waste regardless of waste volume, it is stable, standardized, does not need specific expertise, the produced heat energy is recyclable, the MW is well disinfected/sterilized, and the pollutants are removed. No method is ideal, so there are also several disadvantages in incineration such as air pollution, production of toxic and carcinogenic substances (dioxins, polychlorinated biphenyls, polycyclic aromatic compounds) and harmful gases $(\mathrm{HCl}, \mathrm{HF}$, $\left.\mathrm{SO}_{2}\right)[72,117,118]$.

According to the Greek regulations, incineration is appropriate for the treatment of HMW, and substantially decreases their weight and volume. The degree of automation and flexibility is high, while the community acceptance of an incineration facility is reduced compared to alternative treatment technologies $[118,119]$.

Incineration that is performed by burning at very high temperature ensures sterilization and produces a residual ash with minimal volume that is buried in a landfill facility [120]. The main disadvantage of incineration process is the release of toxic gas into the atmosphere. The main toxins that are released during incineration are dioxins, furans, and mercury [70]. Dioxins are organic compounds that consist of two benzene rings connected by two oxygen atoms, containing 4-8 chlorines that substitute hydrogen atoms of the. Their half-life is 7 to 11 years which makes them very persistent and they accumulate in the environment. Moreover, they are well known to be carcinogenic and are also associated with reproductive harm in humans [121]. The chemical structure of furans is similar to that of dioxins, with the only difference of one oxygen atom between the two benzene rings. Their toxic properties are significant. Mercury emissions that come from medical waste incineration account for 3-9\% of total $\mathrm{Hg}$ emissions [122]. The impact of atmospheric $\mathrm{Hg}$ emissions is serious for public health and the environment since $\mathrm{Hg}$ can accumulate in fatty tissue when inhaled. Additionally, they cause harm to the nervous, reproductive, and excretory systems [123]. It is widely acknowledged that reducing dioxin emissions through fabric filters and complete combustion at temperatures above $800{ }^{\circ} \mathrm{C}$ are the most effective methods [124].

\subsection{High Temperature Pyrolysis Technology}

A more technologically advanced technology for MWT is pyrolysis which operates at $540-830{ }^{\circ} \mathrm{C}$, including plasma/laser-based/oxidation and induction-based pyrolysis [115]. High-temperature pyrolysis technology heats the organic components of MW under oxygen-free or -depleted conditions and breaks their chemical bonds, so that the organic compounds with high molecular weight are transformed into combustible liquid and gases. The pyrolysis gas contains $\mathrm{H}_{2}, \mathrm{CH}_{4}, \mathrm{CO}, \mathrm{CO}_{2}$ and other hydrocarbons and volatile organic substances. The temperature and time of pyrolysis a, re substantial while the MW humidity and particle size have a significant impact on the procedure efficiency. The molecular 
structure of the MW defines the pyrolysis procedure. The high temperature pyrolysis technology of MW burns cracked gas and coke. The combustible gas can be used as fuel for the pyrolysis, decreasing its operating cost compared to common incineration. Pyrolysis with a reduced air coefficient, reduces the produced flue gas, while the flue gas purification apparatus is reduced, resulting in a lower overall cost compared the usual incineration. During incineration, dioxins are easily produced because of the high oxygen combustion. Pyrolysis can have absence of oxygen and acid gas elimination, which decreases dioxins creation comparing to conventional incineration. High-temperature pyrolysis MW can directly feed the furnace [125].

In combination with harmless municipal solid waste, pyrolysis treatment technology of MW offers a different approach for the diversification of MWT. Pyrolysis technology has a high energy recovery rate, minimal secondary pollution, and sufficient economics. An equipment set for MW pyrolysis process with simultaneous gas retrieval, almost fully automated, needs little area, conventional equipment's control, industrial function, little market changes, and strong marketing. As mentioned above, pyrolysis technology can use the created gas by the MW treatment to achieve energy circulation, decrease energy consumption, reduce processing costs, and achieve economic viability [114,125-128].

\subsection{Medium Temperature Microwave Technology}

Microwave technology uses $177-540{ }^{\circ} \mathrm{C}$ for reverse polymerization due to high-energy microwaves for degradation of organic substances. Electromagnetic waves (wavelength $1 \mathrm{~mm}-1 \mathrm{~m}$, frequency $300-3000 \mathrm{MHz}$ ) increase the internal energy by vibration/rubbing of molecules' bonds. $\mathrm{N}_{2}$ atmosphere prevents the combustion with oxygen in contrast with high-temperature disinfection. The lower energy and temperature used herein, reduce heat losses, and avoid environmental pollution because of the nontoxic residue after the disinfection procedure. Specially designed microwave apparatus can inactivate SARSCoV-2 [116] and are appropriate for the on-site disinfection of COVID-19 MW. On-site disinfection prevents the risks of time consuming COVID-19 MW transportation. The microwave technology can be combined with autoclaving, with sterilization steam at 93- $177^{\circ} \mathrm{C}[114]$.

Microwaves $(2450 \mathrm{MHz}, 12.24 \mathrm{~cm}$ ) destroy most of the microorganisms. MW water is quickly warmed, and the contagious elements are destroyed because of high temperature. The MW is fed into a shredder and smashed to little pieces. Then, it is moistened, moved to the microwave generators equipped irradiation chamber, and irradiated for $20 \mathrm{~min}$. Finally, the pretreated MW is compacted in containers and joined with the municipal solid waste. The high costs, in combination with operation/maintenance costs eliminates the applicability in emerging nations. The development of comparable methods is occurring now. The cost of a system including a microwave treatment device with the ability to accept $250 \mathrm{~kg} / \mathrm{h}$ of MW, and all its necessary equipment might cost around USD 500.000 [113,118,129].

\subsection{Pressure Steam Sterilization Technology}

The technique is based on the processing of crushed MW at $121^{\circ} \mathrm{C}$ for 20 min under $100 \mathrm{kPa}$. The steam that is generated at these conditions penetrates the waste and subsequently denatures and inactivates microbial proteins. The residual waste can then be either incinerated or sent to a landfill. Although this method can be used for the processing of contaminated clothing, syringes, and microbial culture equipment it is not applicable to tissues and carcasses. The effectiveness of this cheap/low operating cost technique depends on the temperature, time, and quantity of the MW. The main limitation of the technique is the volume of the product is comparable to that of the initial waste. There are toxic emissions and several toxic chemicals, such as formaldehyde, phenol, and mercury cannot be processed $[50,72,117,118]$. The pressure steam sterilization technology public acceptance in Greece is higher compared to that of the incineration technology [130].

High-pressure steam sterilization technology and incineration technology are appropriate for all kinds of MW. High-pressure steam sterilization technology needs a large, 
dedicated autoclave, and generates unstable contaminated compounds. Chemical disinfection is frequently applied to sterilize infectious liquid MW. Still, great volume of waste is difficult to manage. There are many new technologies that could be used to substitute incineration and avoid the toxic emissions produced. Still, these methods are considered undeveloped and hard to apply so they are not often used in China. On the other hand, high-temperature pyrolysis which can be applied on many occasions provides a great recovery rate with fewer pollutants and great financial advantages.

\subsection{Chemical Disinfection Technology}

The chemical disinfection technologies are appropriate for COVID-19 MW after mechanical shredding [114]. The air is passed through a high efficiency filter to absorb shredding aerosol. The crushed MW is further mixed with chemical disinfectants and remains under negative pressure. The organics are degraded, and the infectious microbes are inactivated or destroyed. No residual hazards are left using chemical disinfectants because they kill both microorganisms and bacterial spores [116]. The chemical disinfection of COVID-19 MW can be divided into chlorine- and nonchlorine-based technologies [131]. The chemical disinfection process relies on the use of chemical agents, such as ozone, peracetic acid, sodium hypochlorite, glutaraldehyde, etc., for disinfection of the MW. This approach is effective not only for liquid waste, but also the municipal solid waste treatment. The effectiveness of the procedure depends mainly on the type and biological characteristics of microorganisms, the level of contamination, the chemical composition, temperature, quantity, and concentration of the disinfectant as well as the exposure time, the $\mathrm{pH}$, and the mixing requirements for every kind of waste. Alternatively, chemical waste can be ground prior to exposure to the disinfectant, ensuring by this method adequate exposure of the chemicals to the particles of the MW and easy disposal of the residue. Residual liquid products can be disposed of in the domestic sewer system and solid products in the landfill [118].

In addition, grinding of MW with a rotary crushing apparatus can be applied before exposing it to a liquid chemical disinfectant, ensuring maximum contact and thus sufficient exposure of the chemicals to particles of the MW and aiding easy disposal of any residues. The liquids produced during the process go into the sewer system, and the solid residues are discarded in landfills. Chemical processing is a simple, cheap, and convenient process that results in rapid disinfection and good deodorization of the final product, high waste volume reduction with no production of waste liquid or gas waste. The main disadvantages of the method are the toxicity of the disinfectants for humans and the strict requirements for temperature setting and $\mathrm{pH}$ monitoring. The method is not recommended for radioactive MW from chemotherapy therapy and volatiles [113]. The use of chemicals for disinfection is expected to achieve public acceptance in Greece [118].

\subsection{Plasma Technology}

Plasma technology is a relatively new method based on the use of a gas cloud that is generated by the ionization of an inert gas. This cloud mainly consists of many positively charged, negatively charged, and neutral particles. When electric current passes through this system, the gas is ionized and generates an instant a glow discharge that reaches a very high temperature (up to $3000^{\circ} \mathrm{C}$ ) and results in rapid dehydration and heating of the waste. The product of this procedure is a mixture of combustible gases such as $\mathrm{H}_{2}, \mathrm{CO}$ and alkanes. Following a second combustion, all pathogenic microorganisms in the waste are destroyed. The final product can be safely disposed of in a landfill. The effectiveness of this expensive technique depends on the power of the instrumentation since the higher energy output, facilitates the temperature conversion. This method is appropriate for all forms of MW since no harmful products are released, the end volume is significantly reduced, and the heat energy that is produced can be recycled [132-134]. 


\subsection{Torrefaction Technology}

Torrefaction is the process by which biomass is depolymerized. A considerable amount of time is demanded to achieve the degree of depolymerization of the biomass as desired. Time and temperature are the two parameters that define the degree of torrefaction. Torrefaction time applied can also be found in literature as reactor residence time [135]. Reactor residence time start at the point biomass reaches $\left(200^{\circ} \mathrm{C}\right)$. Before that, degradation of biomass has not taken place yet $[136,137]$. Torrefaction can be applied on medical cotton waste (MCW) which is a cellulose-based material structured by around 95\% cellulose [138,139]. There are many treatment methods used to valorize such materials. MCW is usually infected and hazardous. It should be sterilized to remove any pathogenic or infectious substances that might be harmful. To accomplish this, it is placed in an autoclave at $121^{\circ} \mathrm{C}, 15 \mathrm{bar}$, for $15 \mathrm{~min}$ to destroy any infectious bacteria or possible viruses. This method is efficient for the sanitization of MCW [140,141].

\subsection{Acid and Enzymatic Hydrolysis Technology}

Acid hydrolysis is a common technology widely used to achieve the transformation of biomass into monosaccharides. Some of the major acids used for hydrolysis are $\mathrm{HCl}$, $\mathrm{H}_{2} \mathrm{SO}_{4}, \mathrm{HNO}_{3}$, etc. This technology results in a greater sugar yield than other methods used for the same reason. It also provides good reproducibility [142]. Although acid hydrolysis creates a high sugar yield, it also creates a considerable volume of degradation products such as furfural, hydroxymethylfurfural, formic acid and levulinic acid. To minimize the degradation products, parameters such as the type of acid, $\mathrm{pH}$, temperature, and time must be chosen appropriately. The acid hydrolysis technology can be applied to MCW for fermentable to bioethanol sugars production. Enzymatic hydrolysis can be used as a second step during this process [143-145].

Enzymatic hydrolysis, through cellulases, transforms cellulose into fermentable reducing sugars, which are converted by yeasts or bacteria to ethanol $[146,147]$. This process is a multistep reaction that occurs in a heterogeneous system. Insoluble cellulose initially separated into solid-liquid phase via endoglucanases and exoglucanases/cellobiohydrolases. As a next step, glucose is produced from $\beta$-glucosidase [148] through halfway product hydrolysis in the liquid phase. Such products are short cellulo-oligosaccharides and cellobiose. Enzymolysis, as a process, is cheaper than acid or alkaline hydrolysis since it occurs in moderate conditions and avoids corrosion [149]. Hydrolyzed cellulases may be produced by bacteria or fungi. Cellulosic enzymatic hydrolysis is a three-step procedure: (i) adsorption of cellulases to the surface of the cellulose, (ii) hydrolysis of cellulose to glucose, and (iii) desorption of cellulases [150]. Substrate concentration plays a critical role in the amount of yield and initial rate of enzymatic hydrolysis of cellulose. When substrate levels are low, there is need of increase in its concentration to expand yield and reaction rate of the hydrolysis [151]. High concentration enzyme usage with the supplementation of $\beta$-glucosidases during hydrolysis, with simultaneous reduce of sugars during hydrolysis by ultrafiltration or simultaneous saccharification and fermentation (SSF), is among the major methods that reduce the inhibition of hydrolysis [145] Moreover, optimized high solids loading enzymatic hydrolysis/fermentation of cotton dust was achieved by Vignesh and Chandraraj [152] using surfactant as additive.

\section{Energy, Fuels and Materials Produced by Medical Waste Treatment}

The MWTTs energy recovery efficiencies (EREs) and impact on the environment can be estimated [93]. MWTTs such as incineration (rotary kiln or pyrolysis), plasma melting, and sterilization (steam or microwave), were studied using energy recovery analysis (ERA), LCA, and life cycle costing (LCC) methods. Moreover, incineration and sterilization MWTTs combined with co-incineration technologies gave improved energy recovery potential and improved environmental behavior. ERA estimated high ERE 83.4\% for 'steam and microwave sterilization + incineration' and low ERE 19.2\% for plasma melting. LCA results were encouraging for 'microwave sterilization + landfill' and discouraging for plasma 
melting. According to LCC, pyrolysis incineration had the least economic cost, while plasma melting had the greatest. A low cost was found in the case of co-incineration of sterilized MW and municipal solid waste. These findings by Zhao et al. [93] indicate that pyrolysis incineration is the most advantageous method regarding the economic aspect, while plasma melting has the highest operating cost. Heat from waste is not utilized efficiently enough because of the lack of appropriate methods of heat energy recovery. Northern China uses the MWTT generated energy to provide heat. Southern China uses electrical power generation to utilize MWTT produced heat, although limitations exist due to low power generation efficiency.

Dharmaraj et al. [126] found that pyrolysis is a very effective technology for the degradation of COVID-19 MW. The plastic fraction of COVID-19 MW mainly contains polyethylene (PE), polyethylene terephthalate (PET), polyvinyl chloride (PVC), polystyrene (PS), and polypropylene (PP). This fraction can be pyrolyzed for the production of solid, liquid and gas fuels. Pyrolysis could potentially substitute incineration MWTT as regards the treatment of the MW plastic fraction produced due to the COVID-19 pandemic. It seems to be a less complicated and more environmentally friendly MWTT, resulting in valuable products such as solid and gas fuels. Efficient fuel productions need highly organized MW collection and MW's plastic fraction separation.

Erdogan et al. [134] used plasma gasification technology for $\mathrm{H}_{2}$ and syngas production from MW. A $10 \mathrm{~kW}$ microwave air plasma generator was used, and the operating conditions were defined for maximum $\mathrm{H}_{2}$ production. Although plasma gasification is a promising alternative low cost and sustainable technology for WMTT in the near future, further research is needed because of the lack of information about the harmful substances created during this procedure. The produced harmful substances levels must be below the official limits. Rasul et al. [153] produced liquid fuel oil from the plastic fraction of MW by thermal cracking under oxidizing conditions at $500{ }^{\circ} \mathrm{C}$ for $40 \mathrm{~min}$. The liquid fuel yield was $52 \%$ and $\mathrm{HHV}$ was $41.32 \mathrm{MJ} / \mathrm{kg}$, i.e., comparable to commercial diesel. This pyrolytic MWTT produces clean fuels with a significant energy content, and, similarly to conventional pyrolysis, could substitute the incineration method. On the other hand, thermal cracking is not a mature MWTT, while it is not applied in large scale for MWT, and further pilot scale investigation is required. Similarly, Som et al. [154] produced pyrolytic oil by thermal pyrolysis of plastic fraction MW at 200-300 ${ }^{\circ} \mathrm{C}$. The pyrolytic oil's density was $840 \mathrm{~kg} / \mathrm{m}^{3}$, the HHV was $24.2 \mathrm{MJ} / \mathrm{kg}$ and the flash point is $39^{\circ} \mathrm{C}$. The maximum yield reached $53 \%$, which is a promising result. Pyrolytic oil could substitute commercial diesel since they have similar HHV. They followed the trend of using pyrolysis as an alternative MWTT for the MW plastic fraction, which comes in complete agreement with Dharmaraj et al. [122] research.

Shen et al. [155] applied the co-hydrothermal carbonization technology to PVC containing MW mixed with lignocellulosic biomass (woodchips) and produced solid fuel in lab-scale and pilot-scale. In the pilot-scale application of the hydrothermal carbonization process, the presence of woodchips improved the dichlorination efficiency of MW. The low chlorine containing hydrochar product had better HHV $(24.2 \mathrm{MJ} / \mathrm{kg})$ and was appropriate to be used as a clean coal substitute, i.e., as an alternative fuel. It must be mentioned that with this lab scale autoclave reactor, lignocellulosic biomass has numerous uses for energy and fuel production. The combination of MW plastic fraction with lignocellulosic biomass is an ingenious idea, combining the MWM with lignocellulosic biomass evaluation and solid fuels production. Nevertheless, lignocellulosic biomass can be found in many MW categories, such as medical cotton (almost pure cellulose), cotton-based textiles (mostly cellulose) and paper (mainly cellulose with low amounts of lignin and hemicelluloses). Consequently, there are many opportunities for further investigation on this method application in terms of energy recovery and large-scale economic feasibility.

Fang et al. [156] pyrolyzed mixed MW at $500{ }^{\circ} \mathrm{C}$, produced liquid fuel (pyrolysis oil) and refined it by fractional condensation. The HHV of gas and solid products was $10,995 \mathrm{kcal} / \mathrm{Nm}^{3}$ and $5454 \mathrm{kcal} / \mathrm{kg}$, respectively. This study contributes to the opinion that pyrolysis is a significantly suitable method for MWT. Nevertheless, in this case, the 
pyrolysis feedstock included plastic, cotton, and glassware in considerable amounts. The results agree with the previous results, giving pyrolysis strong fundamentals to soon become the most common MWTT.

Xin et al. [157] applied the torrefaction technology to herbal medicine wastes, the results indicating that the torrefied herbal medicine wastes have great combustion properties and are appropriate to be used as solid fuels, e.g., for co-combustion with other fuels or for production of pellets. Torrefaction is not a common MWTT, and was used in lab scale, including limited MW categories, producing valuable products. However, it is a technology with great applicability in lignocellulosic biomass treatment and enhances the feedstock HHV. If MW separation were more structured, torrefaction might become a feasible MWTT probably in combination with lignocellulosic biomass treatment.

Giakoumakis et al. [145] optimized the production of fermentable sugar by acid pretreatment in combination with enzymatic saccharification of MCW. These sugars were useful for bioethanol production. This sequential procedure is a common method of treating lignocellulosic biomass. The novelty of that attempt was to engage in this procedure and examine its feasibility on MCW. There are strong limitations to this technology because MW separation methods need to be restructured to separate MCW. The results showed a maximum conversion of cellulose to glucose of up to $95.6 \%$. Li et al. [158] and Gan and Peng [159] concluded with similar results using cellulose as feedstock. Moreover, MCW could be separated from mixed MW and gathered with the rest of lignocellulosic MW (textiles, paper, etc.) to be treated appropriately in the future, to enforce the attempt to create recycled green fuels. In addition, Giakoumakis et al. [144], used acid pretreated recycled MCW as high HHV solid fuel. Moreover, they applied the torrefaction technology to produce solid fuels with enhanced HHV from MCW [136]. The torrefied MCW can also be used as an adsorbent for industrial liquid waste cleaning. The results showed that the MCW substitute had similar properties to those of common commercial cotton, in both cases of torrefaction and acid hydrolysis treatment. Torrefaction, similarly, to acid hydrolysis, is a well-tested treatment method for biomass. There is space in the future for these technologies to become part of the MWTTs and contribute to a wide range of applications besides liquid/solid fuels and adsorbent production.

Das et al. [160] treated waste disposable syringes by thermolysis (pyrolysis at $400-550{ }^{\circ} \mathrm{C}$ ) in a semi-batch reactor made up of stainless steel to produce liquid fuel. These syringes had bodies of polypropylene and pistons of high-density polyethylene. The produced pyrolysis oil had physical properties similar to a diesel or petrol mixture. So, pyrolysis is a highly efficient MWTT regarding MW plastic fraction treatment. This comes into total agreement with the literature that states that pyrolyzed MW plastic fraction produces value added fuels.

Baghdadi et al. [161] produced a fibrous cellulose sulfate absorbent from MCW. This adsorbent was synthesized by sulfonation of MCW using CSA in DMF medium and was found appropriate for malachite green removal from aqueous solutions using batch and column apparatus.

Mohseni-Bandpei et al. [162] produced char and oil by fast pyrolysis of HMW and found the formation of polycyclic aromatic hydrocarbons depending on the operating conditions. Fast pyrolysis technology can convert the MW to a useful hydrocarbon fuel. Fast pyrolysis is another pyrolytic application, for chemicals and fuel production based on MW mixtures containing plastic, paper, textiles, and glassware that demonstrates the pyrolysis advantages as a promising common MWTT.

Ismail and Talib [163] produced biogas from industrial recycled MCW using thermophilic bio-digestion conditions to improve the biogas yield by $92 \%$. Anaerobic digestion is a common technology for municipal waste organic fraction treatment, but not a conventional MWTT. The enhanced MW categorization/separation is expected to contribute to the path of energy and fuels production from cellulosic and lignocellulosic MW fractions such as MCW via several technologies such as anaerobic digestion, competitive to the traditional incinerating MWTTs. 
Arcuri et al. [164] constructed a bioanode, as the first step of an enzymatic fuel cell prototype fabrication appropriate, for energy production from blood and saliva in infectious MW. An enzymatic fuel cell could be an appropriate electrochemical device for the conversion of the stored chemical energy into electricity via oxidization of the substrate. This innovative laboratory scale MWT approach, must be considered far away from pilot scale application as a mature MWTT.

Alam et al. [165] used a mixture of hydrothermally treated MW, pyrolytic plastic waste residue and biomass to produce low chlorine fuel pellets with $22 \mathrm{MJ} / \mathrm{kg} \mathrm{HHV}$ which is like that of coal. Hydrothermally treated, disinfected MW, untreated and hydrothermally pretreated rice straw, fir sawdust, and pyrolyzed plastic waste were used for the preparation of thirteen types of fuel pellets. Most of the single feedstock made pellets failed to meet the specifications of the E.U. requirements, while most combined fuel pellets complied with the E.U. requirements. The pellets' chlorine and ash content caused a specification problem. On the other hand, the combined fuel pellets had a gross calorific value comparable to coal. In fact, the produced fuel pellets showed considerably higher $\mathrm{O} / \mathrm{C}$ and $\mathrm{H} / \mathrm{C}$ ratios compared to coal. Furthermore, mixed feedstock fuel pellets enhanced the fuel pellet quality. As a conclusion, low-chlorine clean lignocellulosic biomass fuel pellets of high gross calorific value can be successfully mixed with hydrothermally treated MW and pyrolytic plastic waste residue. This is a brilliant approach to combining three different kinds of pretreated waste, i.e., MW, plastic residue, and lignocellulosic biomass, in a common treatment process, i.e., pelletizing, for added value in solid fuel production.

Manegdeg et al. [166] used a pyrolyzer-Rankine cycle for MWT and electricity production from MW. They found that by employing a pyrolyzer-Rankine cycle power plant to produce electricity from MW is feasible and profitable $400 \%$ in a 5-year cycle. Furthermore, Bujak [167] used a rotary kiln for MW thermal treatment and found that from $180 \mathrm{~kg} / \mathrm{h}$ of MW, the produced heat flux was $835.6 \mathrm{~kW}$, the total thermal efficiency was $66.8 \%$, the $\mathrm{CO}_{2}$ emissions were significantly reduced, and the project's internal rate of return was $18.6 \%$. This experiment lasted one month, providing sufficient information regarding economic, environmental, and energy production aspects. It was proven to be a cost-effective approach, with low daily greenhouse emissions and emissions well below average, while providing a significant amount of energy. It achieved significant on-site heat recovery during MW incineration. Moreover, he used an incinerator for MW [168], obtaining $6.6-8 \mathrm{~kW} / \mathrm{kg}$ energy corresponding to $10-12 \mathrm{~kg} / \mathrm{kg}$ of saturated steam, while $4.15 \mathrm{~kW} / \mathrm{kg}$ heat flux was used as additional fuel. The incinerator's energy efficiency coefficient was $47-62 \%$. Finally, he used systems for heat recovery from MW thermal treatment [169].

Świechowski et al. [170] used the torrefaction method to produce carbonized solid fuel from waste of medical peat. Torrefaction at $200-550{ }^{\circ} \mathrm{C}$ improved the peat waste HHV up to $21.3 \mathrm{MJ} / \mathrm{kg}$ compared to $19.0 \mathrm{MJ} / \mathrm{kg}$ of the untreated material. This was the first attempt to utilize torrefied medical peat, i.e., an innovative approach for lignocellulosic MW use on lab scale, showing the need for further investigation and upscaling of MW fractions torrefaction as an alternative MWTT. Chaiyat [171] used an organic Rankine cycle in combination with an infectious MW incinerator for energy production and evaluated the system by energy, exergy, economic, and environmental analysis. The system produces $23.65 \mathrm{~kW}_{\mathrm{e}}$ while energy and exergy efficiency were only $0.91 \%$ and $0.89 \%$, respectively. Further investigation is required, and many improvements must be made in concern of energy production and system efficiency improvement, since the hot fluid and hot water loops could be connected in one cycle.

In Table 4 are presented various MW treatment technologies and the produced energy, fuels, and materials potential. Moreover, Figure 3, is presenting a simplified schematic diagram of energy (heat and power), fuels (gas, liquid, solid) and materials (adsorbents) production from MW and MW fractions (plastic, cotton, blood, saliva) using various treatment technologies (acid hydrolysis, combined acid and enzymatic hydrolysis, anaerobic digestion, enzymatic oxidation, hydrothermal treatment, incineration, pyrolysis, microwave or steam sterilization, plasma gasification/melting, sulfonation, and torrefaction). 
Table 4. Medical waste (MW) treatment technologies and energy/fuels/materials production.

\begin{tabular}{|c|c|c|c|c|c|c|}
\hline Country & Material & Technology & Fuels/Materials & $\begin{array}{l}\text { Energy } \\
\text { Content }\end{array}$ & $\begin{array}{l}\text { Energy/Recovery } \\
\text { Efficiency }\end{array}$ & Reference \\
\hline Bangladesh & plastic MW & $\begin{array}{l}\text { Thermal cracking } \\
\text { (Batch reactor) }\end{array}$ & Liquid $52 \%$ & $41.3 \mathrm{MJ} / \mathrm{kg}$ & & [153] \\
\hline Bangladesh & plastic MW & Pyrolysis & Liquid & $41.3 \mathrm{MJ} / \mathrm{kg}$ & & [154] \\
\hline China & MW & $\begin{array}{l}\text { Rotary kiln } \\
\text { incineration }\end{array}$ & & & $64 \%$ & [93] \\
\hline China & MW & $\begin{array}{c}\text { Pyrolysis } \\
\text { incineration }\end{array}$ & & & $55 \%$ & [93] \\
\hline China & MW & Plasma melting & & & $19 \%$ & [93] \\
\hline China & MW & $\begin{array}{c}\text { Steam } \\
\text { sterilization }\end{array}$ & & & $83 \%$ & [93] \\
\hline China & MW & $\begin{array}{l}\text { Microwave } \\
\text { sterilization }\end{array}$ & & & $84 \%$ & [93] \\
\hline China & MW & Incineration & & & $30 \%$ & [82] \\
\hline China & MW & Autoclave & & & $10 \%$ & {$[82]$} \\
\hline China & PVC MW & $\begin{array}{l}\text { Hydrothermal } \\
\text { carbonization }\end{array}$ & $\begin{array}{l}\text { Hydrochar } \\
\text { particles }\end{array}$ & $24.2 \mathrm{MJ} / \mathrm{kg}$ & & [155] \\
\hline China & MW & Pyrolysis & Gas/liquid/solid & $\begin{array}{l}46 \mathrm{MJ} / \mathrm{Nm}^{3} \\
37.6 \mathrm{MJ} / \mathrm{kg}^{\prime} \\
22.8 \mathrm{MJ} / \mathrm{kg}\end{array}$ & & [156] \\
\hline China & $\begin{array}{l}\text { medicine herbal } \\
\text { waste }\end{array}$ & Torrefaction & Solid & $20.3 \mathrm{MJ} / \mathrm{kg}$ & & [157] \\
\hline Greece & cotton MW & $\begin{array}{l}\text { Acid/enzymatic } \\
\text { hydrolysis }\end{array}$ & Bioethanol/sugars & & & [145] \\
\hline Greece & cotton MW & Torrefaction & Solid & $20.1 \mathrm{MJ} / \mathrm{kg}$ & & [136] \\
\hline Greece & cotton MW & Acid hydrolysis & Adsorbent & & & [144] \\
\hline Greece & cotton MW & Torrefaction & Adsorbent & & & [137] \\
\hline India & Medical syringes & Pyrolysis & Gas $17 \%$ & $42.5 \mathrm{MJ} / \mathrm{kg}$ & & [160] \\
\hline India & plastic MW (PET) & Pyrolysis & Liquid/gas & & & [126] \\
\hline India & $\begin{array}{l}\text { plastic MW } \\
\text { (HDPE) }\end{array}$ & Pyrolysis & Liquid/gas & & & [126] \\
\hline India & $\begin{array}{l}\text { plastic MW } \\
\text { (LDPE) }\end{array}$ & Pyrolysis & Gas/liquid/solid & & & [126] \\
\hline India & $\begin{array}{l}\text { plastic MW } \\
\text { (PVC) }\end{array}$ & Pyrolysis & Liquid/gas & & & [126] \\
\hline India & plastic MW (PP) & Pyrolysis & Gas/liquid/solid & & & [126] \\
\hline India & plastic MW (PS) & Pyrolysis & Liquid/gas & & & [126] \\
\hline Iran & cotton MW & Sulfonation & Adsorbent & & & [161] \\
\hline Iran & plastic MW & Pyrolysis & $\begin{array}{c}\text { Solid } 24 \% \text { /gas } \\
2.5 \%\end{array}$ & & & [162] \\
\hline Iraq & cotton MW & $\begin{array}{l}\text { Anaerobic } \\
\text { digestion }\end{array}$ & $\begin{array}{c}\text { Biogas } 51.6 \\
\mathrm{~mL} / \mathrm{g}\end{array}$ & & & [163] \\
\hline Italy & Blood/saliva MW & $\begin{array}{c}\text { Enzymatic } \\
\text { oxidation }\end{array}$ & Electric energy & & & [164] \\
\hline Korea & solid MW & $\begin{array}{l}\text { Hydrothermal } \\
\text { treatment }\end{array}$ & Pellets & $28.3 \mathrm{MJ} / \mathrm{kg}$ & & [165] \\
\hline
\end{tabular}


Table 4. Cont

\begin{tabular}{|c|c|c|c|c|c|c|}
\hline Country & Material & Technology & Fuels/Materials & $\begin{array}{l}\text { Energy } \\
\text { Content }\end{array}$ & $\begin{array}{l}\text { Energy/Recovery } \\
\text { Efficiency }\end{array}$ & Reference \\
\hline Philippines & $\begin{array}{c}\text { noninfectious } \\
\text { MW }\end{array}$ & $\begin{array}{c}\text { Pyrolysis, } \\
\text { Rankine cycle }\end{array}$ & & $30 \mathrm{MJ} / \mathrm{kg}$ & & [166] \\
\hline Poland & MW & $\begin{array}{l}\text { Rotary kiln } \\
\text { incineration }\end{array}$ & & $25 \mathrm{MJ} / \mathrm{kg}$ & & [167] \\
\hline Poland & MW & Incineration & & & $62 \%$ & [168] \\
\hline Poland & MW & $\begin{array}{c}\text { Incineration/Steam } \\
\text { heat recovery } \\
\text { system }\end{array}$ & & & $80 \%$ & [169] \\
\hline Poland & peat MW & Torrefaction & Solid & $21.3 \mathrm{MJ} / \mathrm{kg}$ & & [170] \\
\hline Russia & MW & Pyrolysis & Gas/solid & & & [172] \\
\hline Spain & Plastic MW & Incineration & & $30.7 \mathrm{MJ} / \mathrm{kg}$ & & [173] \\
\hline Thailand & Infectious MW & $\begin{array}{l}\text { Incineration, } \\
\text { Rankine cycle }\end{array}$ & & $51240 \mathrm{kWh} / \mathrm{y}$ & & [171] \\
\hline Turkey & MW & $\begin{array}{c}\text { Plasma } \\
\text { gasification }\end{array}$ & $\mathrm{H}_{2}$ & $5.64 \mathrm{MJ} / \mathrm{m}^{3}$ & & [134] \\
\hline USA & MW & gasification & syngas & & & [174] \\
\hline
\end{tabular}

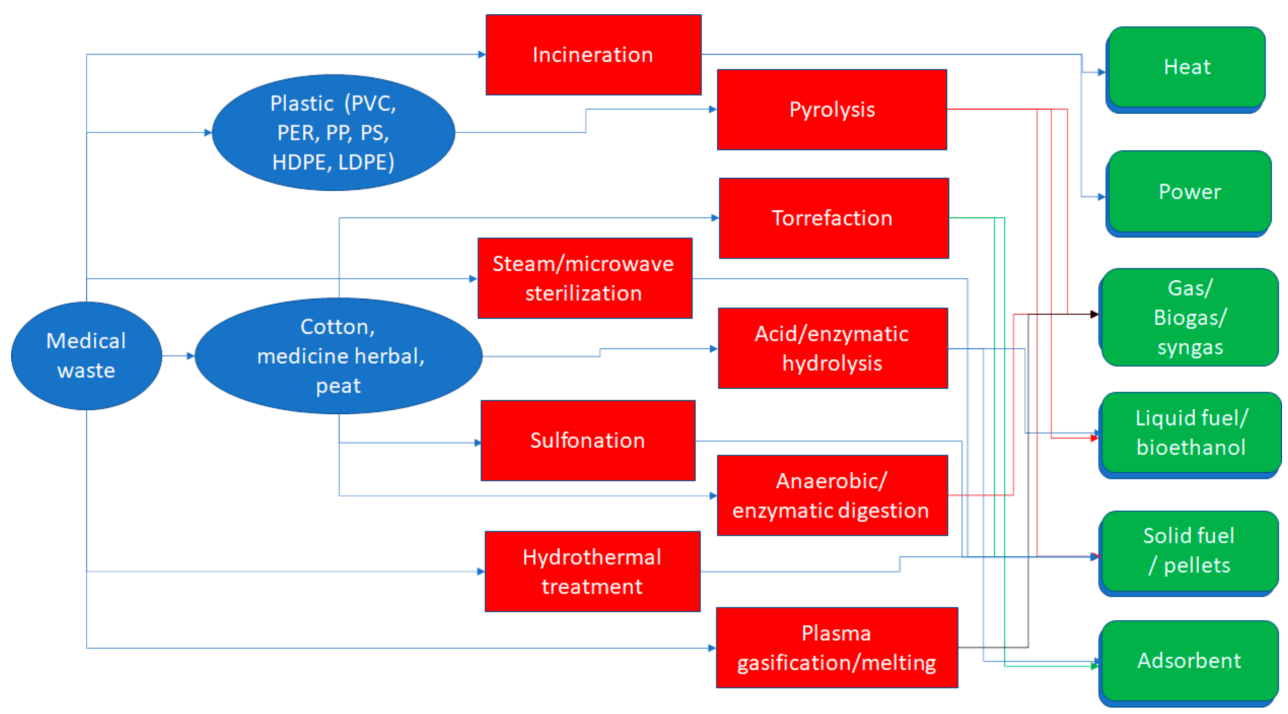

Figure 3. A schematic diagram on energy/fuels/materials production from medical waste and medical waste fractions via various treatment technologies.

5. Optimization Process Limitations, Economic Feasibility, and Recommendations for Future Research

\subsection{Optimization Process Limitations and Economic Feasibility}

The limitations in terms of MWTTs processes optimization and economic feasibility must be considered as regards MWTTs development. Ökten et al. [175] suggested the use of the best available techniques for MWT, mentioning that incineration seems to be the optimal option in terms of public health and environmental protection, but pollutes the air with dioxin, furan, and PCBs, due to incomplete plastics burning. On the other hand, comparing the economic feasibility of the converting, autoclaving, and ozonation MWTTs revealed that ozonation MWTT was the optimal from the economic point of view. Soares et al. [176] used LCA and cost analysis as decision-making tools to define the 
most environmentally friendly MWTT, among (i) microwave, (ii) autoclave and (iii) lime disinfection technology, followed by transportation/landfilling.

Kargar et al. [177] designed an efficient and reliable infectious MW reverse logistics network to control the spread of COVID-19. They achieved the minimization of costs and risks related to the network's operation, dealing with various infectious MWG healthcare facilities. They developed a linear programming model to minimize the total costs, the transportation risks, the infectious MWT risks and the maximum uncollected MW in healthcare facilities. Similarly, Govindan et al. [98] developed a bi-objective mixed-integer linear programming model for MWM during the COVID-19 pandemic, by simultaneously minimizing the total costs and of the population's exposure to pollution risks. Additionally, He et al. [14] used the operational flow of MW to optimize the automated MW sorting system problem, using a mixed-integer programming model for the MW assignment, presorting stations, and automated guided vehicles optimization.

Liu et al. [178] proposed coordinating governments, hospitals, communities, and other departments in the MWD process, as well as developing guidelines for MWD nationwide to deal with potential risks and optimize MWM systems using the green governance principle. Torkayesh et al. [179] developed a novel multi-objective optimization model to assist the optimized decision-making by the MWG companies, considering the economic/environmental/social aspects of the sustainability concept. They aimed to minimize the transportation/processing/establishment costs, as well as the MW transportation environmental risks/emissions in combination with the maximization of job creation opportunities. They investigated the applicability and feasibility of an Improved Multi-Choice Goal Programing approach as regards multi-objective optimization model solving. Ghannadpour et al. [180] used a self-adaptive evolutionary algorithm for triple bottom-line objective optimization of sustainable MW collection and routing.

Rolewicz-Kalińska [181] focused on the logistic factors in an MWM system, considering current legal constraints, organizational factors, and economic aspects. An MWM system's structure must include the goals and constraints as regards their implementation in full scale. The sustainable function of an MWM system needs effective MW logistics and sense of balance among MWG locations and MWT services. Van Straten et al. [182] investigated the applicability of the circular economy concept for recycling stainless-steel MW and reusing old medical instruments. They found that circularity gives a sustainable model for surgical MWM, with cost reduction and environmental advantages.

According to Yao et al. [183], the solution to the complex relationships among stakeholders is to find the optimal locations of the MW disposal centers. They reduced risks and mitigated costs by optimizing the MW disposal centers location-allocation problem using a soft-path solution, i.e., a risk mitigation-oriented bilevel equilibrium optimization model employing the Stackelberg game behavior as regards local government and healthcare facilities.

Arun and Wang [184] investigated the implementation of industry 4.0 to decrease procedural MW, considering the system/service/procedural/product hierarchical innovation levels. They found that industry 4.0 concept application contributes to a more efficient use of resources in the healthcare sector, but more research is required as regards its impact on the production of procedure-caused MW. Ranjbari et al. [185] worked on the (i) mapping of the research and development on MW, (ii) identification of the research themes/trends, and (iii) development of an MWM research agenda within the circular economy transition and sustainable environmental concepts. They highlighted (a) MW minimization, sustainable management, and policymaking, (b) MW incineration and its environmental effects, (c) HMW management practices, and (d) MW handling and occupational safety and training. Chaerul et al. [186] presented a design model centered to a trans-shipment goal programming methodology and perfecting the MW flow as regards multiple goals in numerous significance structures of comparative importance. They found that, adjustment to economic and environmental pollution standards is necessary when the MWM is prejudiced towards a greater degree of security control. Nursetyowati et al. [187] achieved the goal of choosing the most optimal alternative for hazardous MWM (reducing, sorting, storing, 
transporting, treatment, until burial), by conducting pair comparisons, with Expert Choice 11 software for the data processing. Finally, Mei et al. [188] constructed a multi-phase MW emergency reverse logistics system siting standard to reduce the expense, the safety threat, and the schedule for the safe and quick MW disposal, considering bottlenecks of the current facilities' disposal capability due to the COVID-19 pandemic.

\subsection{Recommendations for Future Research}

Recommendations for future research to possibly overcome the above limitations follow:

- More work can be conducted as regards the optimization of the MW collection and transportation processes, in combination with the location/allocation of MWT facilities installation problem.

- The categorization and separation of MW can be significantly improved, while the segregation of MW at the location where it is generated (hospitals, healthcare facilities, etc.) can substantially enhance the economic feasibility of the following steps as regards the MWTTs applied for energy, fuels, and materials production.

- The thermal energy produced during MWT via incineration and similar technologies can be utilized more efficiently by innovative recycling and recovering techniques while the environmental impact via thermal pollution will be eliminated.

- The determination of the HHV values and the physical/chemical properties of the specific MW fractions will facilitate the processes optimization and the costs minimization.

- MWTTs data from pilot and full-scale MWT facilities can be collected to improve the accuracy and universality of the processes optimization results and the economic feasibility of the proposed applications.

- Further research is needed on the application of the MW plastic or lignocellulosic fraction (cotton, paper/cardboard, textiles) conversion technologies, focusing on the fuels/materials production.

- $\quad$ Finally, more work can be conducted on the co-processing of the MW plastic or lignocellulosic fraction (cotton/paper/cardboard/textiles) with similar fractions coming from municipal/industrial solid waste (plastics or cotton/paper/cardboard/textiles/wood) or agricultural (straw / wood/husks/chaff/cobs/bagasse can) and forest (wood/bark/ leaves/stems/roots) lignocellulosic biomass, aiming at value added fuels/materials production technologies with low-cost (see Figure 4).

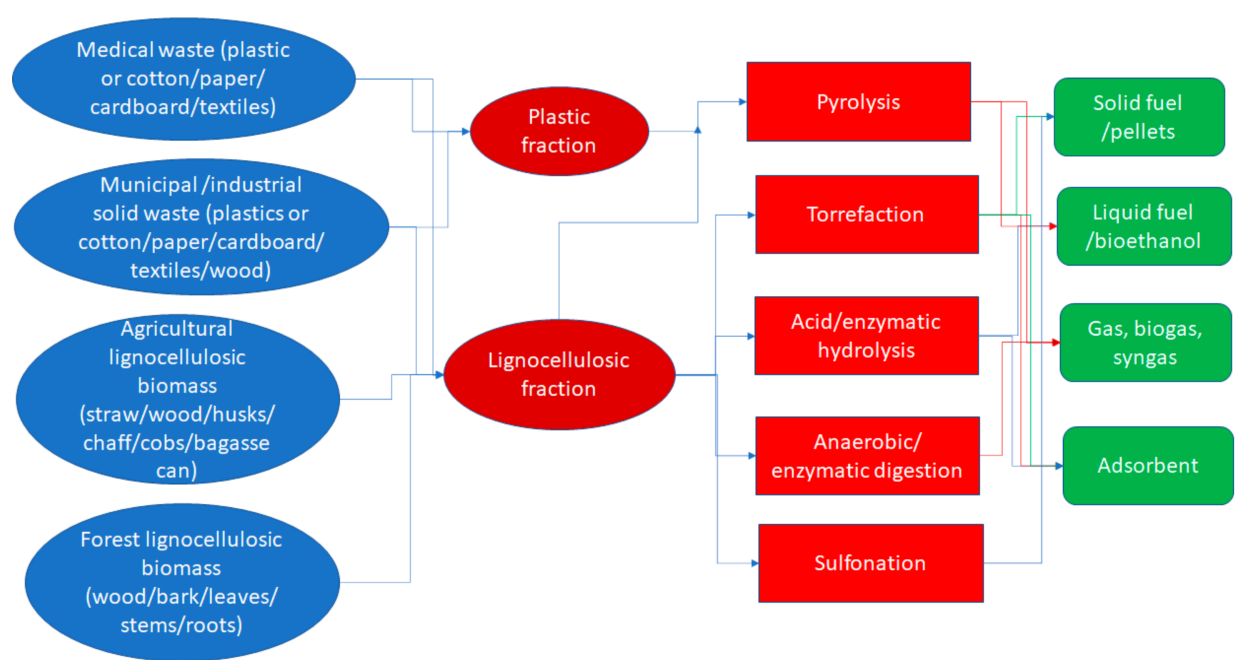

Figure 4. A schematic diagram on co-processing of the plastic/lignocellulosic fraction of medical waste with municipal/industrial solid waste fractions and/or agricultural/forest lignocellulosic biomass for fuels/materials. 


\section{Conclusions}

In conclusion, MWTTs can be divided into (i) large scale MWTTs such as incineration (combined or not with steam heat recovery system), pyrolysis (in combination or not with Rankine cycle), rotary kiln treatment, microwave/steam sterilization, and plasma gasification/melting, and (ii) laboratory scale MWTTs such as acid hydrolysis, combined acid and enzymatic hydrolysis, anaerobic digestion, autoclaving, enzymatic oxidation, hydrothermal carbonization/treatment, sulfonation, batch reactor thermal cracking, and torrefaction. The large scale MWTTs are applicable to the MW as a whole or to most of the major MW segregation fractions (e.g., plastics or lignocellulose). Among them, incineration seems to be the most applied and mature MWTT, producing, e.g., approximately $30 \mathrm{MJ} / \mathrm{kg}$ (heat and power) with up to $80 \%$ recovery efficiency. The rest of the large scale MWTTs can be considered as alternatives to incineration and can be applied primarily on specific fractions of MW, in a more environmentally friendly manner compared to the incineration process. Pyrolysis can be mainly applied to the plastic fraction of the MW and produces gas, liquid, and solid fuel with $\mathrm{HHV}$, e.g., approximately equal to $46 \mathrm{MJ} / \mathrm{Nm}^{3}, 38 \mathrm{MJ} / \mathrm{kg}$, and $23 \mathrm{MJ} / \mathrm{kg}$, respectively. The laboratory scale MWTTs are mainly on experimental stage, and they focus on using MW fractions such as cotton, paper, cardboard, textiles etc. (i.e., the cellulosic/lignocellulosic fraction) as feedstock to produce (a) materials (adsorbents, fermentable sugars, etc.), (b) gas fuels (biogas, syngas, hydrogen, etc.), (c) liquid fuels (biooil, bioethanol, etc.), and (d) solid fuels (pellets, hydrochar particles, etc.). Further research is required on the co-processing of the MW plastic and/or cellulosic/lignocellulosic fraction with analogous municipal/industrial solid waste and/or agricultural/forest lignocellulosic biomass fractions targeted for commercial fuels/materials production. Finally, more work is needed to go from laboratory scale MWTTs to full-scale facilities with increased energy efficiency, optimized materials output, high economic feasibility, and improved sustainability within the zero-waste circular economy concept.

Author Contributions: Conceptualization, G.G.; investigation, G.G.; visualization, D.P.; supervision, D.S. All authors have read and agreed to the published version of the manuscript.

Funding: This research received no external funding.

Institutional Review Board Statement: Not applicable.

Informed Consent Statement: Not applicable.

Data Availability Statement: The study does not report any data.

Acknowledgments: The authors would like to acknowledge administrative and technical support by the University of Piraeus Research Center.

Conflicts of Interest: The authors declare no conflict of interest.

\section{References}

1. Das, A.K.; Islam, M.; Billah, M.; Sarker, A. COVID-19 pandemic and healthcare solid waste management strategy-A mini-review. Sci. Total Environ. 2021, 778, 146220. [CrossRef] [PubMed]

2. Barua, U.; Hossain, D. A review of the medical waste management system at Covid-19 situation in Bangladesh. J. Mater. Cycles Waste Manag. 2021, 23, 2087-2100. [CrossRef]

3. Alrawi, A.S.; Amin, S.A.; Al-Ani, R.R. Medical waste management during COVID-19 pandemic, a review study. IOP Conf. Ser. Earth Environ. Sci. 2021, 779, 012130. [CrossRef]

4. Fadaei, A. Study of solid waste (municipal and medical) management during the COVID-19 pandemic: A review study. Rev. Environ. Health 2021. [CrossRef]

5. Kenny, C.; Priyadarshini, A. Review of Current Healthcare Waste Management Methods and Their Effect on Global Health. Healthcare 2021, 9, 284. [CrossRef]

6. Khan, B.A.; Cheng, L.; Khan, A.A.; Ahmed, H. Healthcare waste management in Asian developing countries: A mini review. Waste Manag. Res. 2019, 37, 863-875. [CrossRef]

7. Antoniadou, M.; Varzakas, T.; Tzoutzas, I. Circular Economy in Conjunction with Treatment Methodologies in the Biomedical and Dental Waste Sectors. Circ. Econ. Sustain. 2021, 1, 563-592. [CrossRef] 
8. Singh, N.; Ogunseitan, O.A.; Tang, Y. Medical waste: Current challenges and future opportunities for sustainable management. Crit. Rev. Environ. Sci. Technol. 2021, 1-23. [CrossRef]

9. Capoor, M.R.; Parida, A. Biomedical Waste and Solid Waste Management in the Time of COVID-19: A Comprehensive Review of the National and International Scenario and Guidelines. J. Lab. Phys. 2021, 13, 175-182. [CrossRef]

10. Chisholm, J.M.; Zamani, R.; Negm, A.M.; Said, N.; Abdel Daiem, M.M.; Dibaj, M.; Akrami, M. Sustainable waste management of medical waste in African developing countries: A narrative review. Waste Manag. Res. 2021, 39, 1149-1163. [CrossRef]

11. El-Ramady, H.; Brevik, E.C.; Elbasiouny, H.; Elbehiry, F.; Amer, M.; Elsakhawy, T.; Omara, A.E.-D.; Mosa, A.A.; El-Ghamry, A.M.; Abdalla, N.; et al. Planning for disposal of COVID-19 pandemic wastes in developing countries: A review of current challenges. Environ. Monit. Assess. 2021, 193, 592. [CrossRef]

12. Tirkolaee, E.B.; Aydın, N.S. A sustainable medical waste collection and transportation model for pandemics. Waste Manag. Res. 2021, 39, 34-44. [CrossRef]

13. Lotfi, R.; Kargar, B.; Gharehbaghi, A.; Weber, G.-W. Viable medical waste chain network design by considering risk and robustness. Environ. Sci. Pollut. Res. 2021, 1-16. [CrossRef]

14. He, X.; Quan, H.; Lin, W.; Deng, W.; Tan, Z. AGV Scheduling Optimization for Medical Waste Sorting System. Sci. Program. 2021, 2021, 4313749. [CrossRef]

15. Song, Y.; Ye, J.; Liu, Y.; Zhong, Y. Estimation of Solid Medical Waste Production and Environmental Impact Analysis in the Context of COVID-19: A Case Study of Hubei Province in China. Preprints 2021, 2021040327. [CrossRef]

16. Kalantary, R.R.; Jamshidi, A.; Mofrad, M.M.G.; Jafari, A.J.; Heidari, N.; Fallahizadeh, S.; Arani, M.H.; Torkashvand, J. Effect of COVID-19 pandemic on medical waste management: A case study. J. Environ. Health Sci. Eng. 2021, 19, 831-836. [CrossRef]

17. Maalouf, A.; Maalouf, H. Impact of COVID-19 pandemic on medical waste management in Lebanon. Waste Manag. Res. 2021, 39, 45-55. [CrossRef]

18. Mekonnen, B.; Solomon, N.; Wndimu, W. Healthcare Waste Status and Handling Practices during COVID-19 Pandemic in Tepi General Hospital, Ethiopia. J. Environ. Public Health 2021, 2021, 6614565. [CrossRef]

19. Khalid, S.; Haq, N.; Sabiha, Z.-U.; Latif, A.; Khan, M.A.; Iqbal, J.; Yousaf, N. Current practices of waste management in teaching hospitals and presence of incinerators in densely populated areas. BMC Public Health 2021, 21, 1340. [CrossRef]

20. Nguyen, T.D.; Kawai, K.; Nakakubo, T. Estimation of COVID-19 waste generation and composition in Vietnam for pandemic management. Waste Manag. Res. 2021, 39, 1356-1364. [CrossRef]

21. Tsai, W.T. Analysis of medical waste management and impact analysis of COVID-19 on its generation in Taiwan. Waste Manag. Res. 2021, 39, 27-33. [CrossRef] [PubMed]

22. Anicetus, H.; Saria, J.; Mohamed, H. Estimation of Different Categories of Healthcare Waste Generated at Two Different Hospital Categories in Four Hospitals in Dar es Salaam City. J. Environ. Prot. 2020, 11, 872-888. [CrossRef]

23. Borowy, I. Medical waste: The dark side of healthcare. Hist. Cienc. Saude-Manguinhos 2020, 27, 231-251. [CrossRef] [PubMed]

24. Meleko, A.; Tesfaye, T.; Henok, A. Assessment of Healthcare Waste Generation Rate and Its Management System in Health Centers of Bench Maji Zone. Ethiop. J. Health Sci. 2018, 28, 125-134. [CrossRef] [PubMed]

25. Minoglou, M.; Gerassimidou, S.; Komilis, D. Healthcare Waste Generation Worldwide and Its Dependence on Socio-Economic and Environmental Factors. Sustainability 2017, 9, 220. [CrossRef]

26. Maamari, O.; Brandam, C.; Lteif, R.; Salameh, D. Health Care Waste generation rates and patterns: The case of Lebanon. Waste Manag. 2015, 43, 550-554. [CrossRef]

27. Debere, M.K.; Gelaye, K.A.; Alamdo, A.G.; Trifa, Z.M. Assessment of the health care waste generation rates and its management system in hospitals of Addis Ababa, Ethiopia, 2011. BMC Public Health 2013, 13, 28. [CrossRef]

28. Komilis, D.P.; Voudrias, E.A.; Anthoulakis, S.; Iosifidis, N. Composition and production rate of solid waste from dental laboratories in Xanthi, Greece. Waste Manag. 2009, 29, 1208-1212. [CrossRef]

29. Komilis, D.; Katsafaros, N.; Vassilopoulos, P. Hazardous medical waste generation in Greece: Case studies from medical facilities in Attica and from a small insular hospital. Waste Manag. Res. 2011, 29, 807-814. [CrossRef]

30. Komilis, D.; Fouki, A.; Papadopoulos, D. Hazardous medical waste generation rates of different categories of health-care facilities. Waste Manag. 2012, 32, 1434-1441. [CrossRef]

31. Hamoda, H.M.; El-Tomi, H.N.; Bahman, Q.Y. Variations in Hospital Waste Quantities and Generation Rates. J. Environ. Sci. Health Part A 2005, 40, 467-476. [CrossRef]

32. Altin, S.; Altin, A.; Elevli, B.; Cerit, O. Determination of Hospital Waste Composition and Disposal Methods: A Case Study. Pol. J. Environ. Stud. 2003, 12, 251-255.

33. Tudor, T.L.; Marsh, C.L.; Butler, S.; Van Horn, J.A.; Jenkin, L.E.T. Realising resource efficiency in the management of healthcare waste from the Cornwall National Health Service (NHS) in the UK. Waste Manag. 2008, 28, 1209-1218. [CrossRef]

34. De Delmonico, D.V.G.; dos Santos, H.H.; Pinheiro, M.A.; de Castro, R.; de Souza, R.M. Waste management barriers in developing country hospitals: Case study and AHP analysis. Waste Manag. Res. 2017, 36, 48-58. [CrossRef]

35. Hossain, S.; Santhanam, A.; Nik Norulaini, N.A.; Mohd Omar, M.K. Clinical solid waste management practices and its impact on human health and environment-A review. Waste Manag. 2011, 31, 754-766. [CrossRef]

36. Tesfahun, E.; Kumie, A.; Beyene, A. Developing models for the prediction of hospital healthcare waste generation rate. Waste Manag. Res. 2015, 34, 219-220. [CrossRef] 
37. Ansari, M.; Ehrampoush, M.H.; Farzadkia, M.; Ahmadi, E. Dynamic assessment of economic and environmental performance index and generation composition, environmental and human health risks of hospital solid waste in developing countries; A state of the art of review. Environ. Int. 2019, 132, 105073. [CrossRef]

38. Farzadkia, M.; Emamjomeh, M.M.; Golbaz, S.; Sajadi, H.S. An investigation in hospital solid waste management in Iran. Glob. NEST J. 2015, 17, 771-783.

39. Sanida, G.; Karagiannidis, A.; Mavidou, F.; Vartzopoulos, D.; Moussiopoulos, N.; Chatzopoulos, S. Assessing generated quantities of infectious medical wastes: A case study for a health region administration in Central Macedonia, Greece. Waste Manag. 2010, 30, 532-538. [CrossRef]

40. Zamparas, M.; Kalavrouziotis, I.K. Healthcare waste management in Greece. The example of Health Region of Western Greece, Peloponnese, Epirus and Ionian Islands. Glob. NEST J. 2017, 20, 96-102. [CrossRef]

41. Zamparas, M.; Kapsalis, V.C.; Kyriakopoulos, G.L.; Aravossis, K.G.; Kanteraki, A.E.; Vantarakis, A.; Kalavrouziotis, I.K. Medical waste management and environmental assessment in the Rio University Hospital, Western Greece. Sustain. Chem. Pharm. 2019, 13, 100163. [CrossRef]

42. Munir, S.; Batool, S.A.; Chaudhry, M.N. Characterization of hospital waste in Lahore, Pakistan. Chin. Med. J. 2014, 127, 1732-1736.

43. Taghipour, H.; Mosaferi, M. Characterization of medical waste from hospitals in Tabriz, Iran. Sci. Total Environ. 2009, 407, 1527-1595. [CrossRef] [PubMed]

44. Gusca, J.; Kalnins, S.N.; Blumberga, D.; Bozhko, L.; Khabdullina, Z.; Khabdullin, A. Assessment Method of Health Care Waste Generation in Latvia and Kazakhstan. Energy Procedia 2015, 72, 175-179. [CrossRef]

45. United States Environmental Protection Agency (EPA). Medical Waste. Available online: https://www.epa.gov/rcra/medicalwaste (accessed on 28 October 2021).

46. Sawalem, M.; Selic, E.; Herbell, J.-D. Hospital waste management in Libya: A case study. Waste Manag. 2009, $29,1370-1375$. [CrossRef]

47. Imdad, S.; Anwar, S.; Shoukat, M.S. Healthcare waste: Evaluation of its generation rate and management practices in tertiary care hospitals of Lahore. Ann. King Edw. Med. Univ. 2013, 19, 274-281. [CrossRef]

48. Ali, S.; Mahmood, U.; Malik, A.U.; Aziz, F.; Naghman, R.B.; Ahmed, I. Current hospital waste management practices in Pakistan: Case study and curative measures. J. Prev. Med. 2015, 1, 125-129.

49. Al-Khatib, I.A.; Khalaf, A.-S.; Al-Sari, M.I.; Anayah, F. Medical waste management at three hospitals in Jenin district, Palestine. Environ. Monit. Assess. 2019, 192, 10. [CrossRef]

50. Windfeld, E.A.; Brooks, S.L.M. Medical waste management-A review. J. Environ. Manag. 2015, 163, 98-108. [CrossRef]

51. Nguyen, D.L.; Bui, X.T.; Nguyen, T.H. Estimation of Current and Future Generation of Medical Solid Wastes in Hanoi City, Vietnam. Int. J. Waste Resour. 2014, 4, 1-5. [CrossRef]

52. Alwabr, G.M.A.; Al-Mikhlafi, A.S.; Al-Hakimi, S.A.; Dughish, M.A. Determination of medical waste composition in hospitals of Sana'a city, Yemen. J. Appl. Sci. Environ. 2016, 20, 343-347. [CrossRef]

53. World Health Organization (WHO). Health-Care Waste. Available online: https://www.who.int/news-room/fact-sheets/detail/ health-care-waste (accessed on 28 October 2021).

54. Korkut, E.N. Estimations and analysis of medical waste amounts in the city of Istanbul and proposing a new approach for the estimation of future medical waste amounts. Waste Manag. 2018, 81, 168-176. [CrossRef]

55. Eker, H.H.; Bilgili, M.S. Statistical analysis of waste generation in healthcare services: A case study. Waste Manag. Res. 2011, 29, 791-796. [CrossRef]

56. Johannessen, L.M. Management of health care waste. In Proceedings of the Environment '97 Conference, Cairo, Egypt, 16-18 February 1997.

57. Kagonji, I.S.; Manyele, S.V. Analysis of the Measured Medical Waste Generation at Amana and Ligula Hospitals Using Statistical Methods. Afr. J. Environ. Sci. Technol. 2011, 5, 815-833.

58. Reinhardt, P.A.; Gordon, J.G. Infectious and Medical Waste Management, 1st ed.; CRC Press: Boca Raton, FL, USA, 1991. [CrossRef]

59. Thakur, V.; Anbanandam, R. Healthcare waste management: An interpretive structural modeling approach. Int. J. Health Care Qual. Assur. 2016, 29, 559-581. [CrossRef]

60. Liberti, L.; Tursi, A.; Costantino, N.; Ferrara, L.; Nuzzo, G. Optimization of Infectious Hospital Waste Management in Italy: Part II. Waste Characterization by Origin. Waste Manag. Res. 1996, 14, 417-431. [CrossRef]

61. Alagöz, B.A.Z.; Kocasoy, G. Treatment and disposal alternatives for health-care waste in developing countries-A case study in Istanbul, Turkey. Waste Manag. Res. 2007, 25, 83-89. [CrossRef]

62. Capoor, M.R.; Bhowmik, K.T. Current perspectives on biomedical waste management: Rules, conventions and treatment technologies. Indian J. Med. Microbiol. 2017, 35, 157-164. [CrossRef]

63. Chen, F.; Lou, J.; Hu, J.; Chen, H.; Long, R.; Li, W. Study on the relationship between crisis awareness and medical waste separation behavior shown by residents during the COVID-19 epidemic. Sci. Total Environ. 2021, 787, 147522. [CrossRef]

64. Chen, Y.; Ding, Q.; Yang, X.; Peng, Z.; Xu, D.; Feng, Q. Application countermeasures of non-incineration technologies for medical waste treatment in China. Waste Manag. Res. 2013, 31, 1237-1244. [CrossRef]

65. Nwachukwu, N.C.; Anayo, F.; Ugbogu, O.C. Health Care Waste Management-Public Health Benefits, and the Need for Effective Environmental Regulatory Surveillance in Federal Republic of Nigeria. Open access peer-reviewed chapter. Curr. Top. Public Health 2013, 2, 149-178. [CrossRef] 
66. Graikos, A.; Voudrias, E.; Papazachariou, A.; Iosifidis, N.; Kalpakidou, M. Composition and production rate of medical waste from a small producer in Greece. Waste Manag. 2010, 30, 1683-1689. [CrossRef] [PubMed]

67. Hama, A.R.; Tahir, T.A.; Ali, B.J. A study on solid waste generation, composition and management in Sulaimania city, Kurdistan region, Iraq. IOP Conf. Ser. Earth Environ. Sci. 2021, 779, 012049. [CrossRef]

68. Hasan, M.M.; Rahman, M.H. Assessment of Healthcare Waste Management Paradigms and Its Suitable Treatment Alternative: A Case Study. J. Environ. Public Health 2018, 2018, 6879751. [CrossRef]

69. Hong, J.; Zhan, S.; Yu, Z.; Hong, J.; Qi, C. Life-cycle environmental and economic assessment of medical waste treatment. J. Clean. Prod. 2018, 174, 65-73. [CrossRef]

70. Insa, E.; Zamorano, M.; Lopez, R. Critical review of medical waste legislation in Spain. Resour. Conserv. Recycl. 2010, 54, 1048-1059. [CrossRef]

71. Jang, Y.C. Infectious/Medical/Hospital Waste: General Characteristics. In Encyclopedia of Environmental Health; Nriagu, J.O., Kacew, S., Kawamoto, T., Eds.; Elsevier: Amsterdam, The Netherland, 2011; pp. 227-231. [CrossRef]

72. Jang, Y.-C.; Lee, C.; Yoon, O.-S.; Kim, H. Medical waste management in Korea. J. Environ. Manag. 2006, 80, 107-115. [CrossRef]

73. Khadem Ghasemi, M.; Mohd Yusuff, R. Advantages and Disadvantages of Healthcare Waste Treatment and Disposal Alternatives: Malaysian Scenario. Pol. J. Environ. Stud. 2016, 25, 17-25. [CrossRef]

74. Kwikiriza, S.; Stewart, A.G.; Mutahunga, B.; Dobson, A.E.; Wilkinson, E. A Whole Systems Approach to Hospital Waste Management in Rural Uganda. Front. Public Health 2019, 7, 136. [CrossRef]

75. Lee, B.-K.; Ellenbecker, M.J.; Moure-Ersaso, R. Alternatives for treatment and disposal cost reduction of regulated medical waste. Waste Manag. 2004, 24, 143-151. [CrossRef]

76. Li, C.; Jenq, F. Physical and Chemical Composition of Hospital Waste. Infect. Control Hosp. Epidemiol. 1993, 14, 145-150. [CrossRef]

77. Mathure, P.; Pathan, S.; Shobhawat, A.S. Need of biomedical waste management system in hospitals-an emerging issue-a review. Curr. World Environ. 2016, 7, 117-124. [CrossRef]

78. Mentzelou, P.; Vosniakos, F.; Dardavesis, T.; Papadakis, N.; Nikolaou, K.; Athansiadou, C. An information system for hospital waste management. J. Environ. Prot. Ecol. 2009, 10, 285-294.

79. Prem Ananth, A.; Prashanthini, V.; Visvanathan, C. Healthcare waste management in Asia. Waste Manag. 2010, 30, $154-161$. [CrossRef]

80. Saxena, P.; Pradhan, I.P.; Kumar, D. Redefining bio medical waste management during COVID-19 in India: A way forward. Mater. Today Proc. 2021. [CrossRef]

81. Phinney, S. 'Greening' Work in Canada-Adapting Canadian Work and Workplaces (ACW) and Canadian Labour Congress (CLC). Available online: https:/ / www.academia.edu/38361995/Greening_Work_in_Canada_Adapting_Canadian_Work_and_ Workplaces_ACW_and_Canadian_Labour_Congress_CLC (accessed on 15 November 2021).

82. Zhao, W.; van der Voet, E.; Huppes, G. Comparative life cycle assessments of incineration and non-incineration treatments for medical waste. Int. J. Life Cycle Assess. 2008, 14, 114-121. [CrossRef]

83. Abd El-Salam, M.M. Hospital waste management in El-Beheira Governorate, Egypt. J. Environ. Manag. 2010, 91, 618-629. [CrossRef]

84. Mandal, S.K.; Dutta, J. Integrated Bio-Medical Waste Management Plan for Patna City; Institute of Town Planners: New Delhi, India, 2009; Available online: http:/ / www.itpi.org.in/pdfs/apr1_09.pdf (accessed on 31 October 2021).

85. Dehghani, M.H.; Azam, K.; Changani, F.; Fard, E.D. Assessment of medical waste management in educational hospitals of tehran university medical sciences. Iran. J. Environ. Health Sci. Eng. 2008, 5, 131-136.

86. Rabeie, O.L.; Miranzadeh, M.B.; Fallah, S.H.; Dehqan, S.; Moulana, Z.; Amouei, A.; Mohammadi, A.A.; Ali Asgharnia, H.; Babaie, M. Determination of Hospital Waste Composition and Management in Amol City, Iran. Health Scope 2012, 1, 127-131. [CrossRef]

87. Bazrafshan, E.; Kord Mostafapoor, F. Survey of medical waste characterization and management in Iran: A case study of Sistan and Baluchestan Province. Waste Manag. Res. 2010, 29, 442-450. [CrossRef]

88. Wajs, J.; Bochniak, R.; Golabek, A. Proposal of a Mobile Medical Waste Incinerator with Application of Automatic Waste Feeder and Heat Recovery System as a Novelty in Poland. Sustainability 2019, 11, 4980. [CrossRef]

89. Abdulla, F.; Abu Qdais, H.; Rabi, A. Site investigation on medical waste management practices in northern Jordan. Waste Manag. 2008, 28, 450-458. [CrossRef] [PubMed]

90. Mohee, R. Medical wastes characterisation in healthcare institutions in Mauritius. Waste Manag. 2005, 25, 575-581. [CrossRef] [PubMed]

91. Sustainability. Roadmap for Hospitals. A Guide to Achieve Your Sustainability Goals. Available online: http://www. sustainabilityroadmap.org/topics/waste.shtml\#.YZIgF07P1PY (accessed on 15 November 2021).

92. Liu, P.; Rani, P.; Mishra, A.R. A novel Pythagorean fuzzy combined compromise solution framework for the assessment of medical waste treatment technology. J. Clean. Prod. 2021, 292, 126047. [CrossRef]

93. Zhao, H.-L.; Wang, L.; Liu, F.; Liu, H.Q.; Zhang, N.; Zhu, Y.W. Energy, environment and economy assessment of medical waste disposal technologies in China. Sci. Total Environ. 2021, 796, 148964. [CrossRef]

94. Bucătaru, C.; Săvescu, D.; Repanovici, A.; Blaga, L.; Coman, E.; Cocuz, M.-E. The Implications and Effects of Medical Waste on Development of Sustainable Society-A Brief Review of the Literature. Sustainability 2021, 13, 3300. [CrossRef]

95. Letho, Z.; Yangdon, T.; Lhamo, C.; Limbu, C.B.; Yoezer, S.; Jamtsho, T.; Chhetri, P.; Tshering, D. Awareness and practice of medical waste management among healthcare providers in National Referral Hospital. PLoS ONE 2021, 16, e0243817. [CrossRef] 
96. Ndejjo, R.; Musinguzi, G.; Yu, X.; Buregyeya, E.; Musoke, D.; Wang, J.-S.; Halage, A.A.; Whalen, C.; Bazeyo, W.; Williams, P.; et al. Occupational Health Hazards among Healthcare Workers in Kampala, Uganda. J. Environ. Public Health 2015, 2015, 913741. [CrossRef]

97. Uddin, M.N.; Islam, M.R.; Yesmin, K. Knowledge on Hospital Waste Management among Senior Staff Nurses Working in a Selected Medical College Hospital of Bangladesh. J. Waste Manag. 2014, 2014, 73069. [CrossRef]

98. Govindan, K.; Nasr, A.K.; Mostafazadeh, P.; Mina, H. Medical waste management during coronavirus disease 2019 (COVID-19) outbreak: A mathematical programming model. Comput. Ind. Eng. 2021, 162, 107668. [CrossRef]

99. Mühlich, M.; Scherrer, M.; Daschner, F.D. Comparison of infectious waste management in European hospitals. J. Hosp. Infect. 2003, 55, 260-268. [CrossRef]

100. Almuneef, M. Effective medical waste management: It can be done. Am. J. Infect. Control 2003, 31, 188-192. [CrossRef]

101. Garcia, R. Effective cost-reduction strategies in the management of regulated medical waste. Am. J. Infect. Control 1999, 27, 165-175. [CrossRef]

102. Blenkharn, J.I. Safe disposal and effective destruction of clinical wastes. J. Hosp. Infect. 2005, 60, 295-297. [CrossRef]

103. Tata, A.; Beone, F. Hospital waste sterilization: A technical and economic comparison between radiation and microwaves treatments. Radiat. Phys. Chem. 1995, 46, 1153-1157. [CrossRef]

104. Brichard, K. Out of sight, out of mind ... the medical waste problem. Lancet 2002, 359, 56. [CrossRef]

105. Solberg, K.E. Trade in medical waste causes deaths in India. Lancet 2009, 373, 1067. [CrossRef]

106. Hantoko, D.; Li, X.; Pariatamby, A.; Yoshikawa, K.; Horttanainen, M.; Yan, M. Challenges and practices on waste management and disposal during COVID-19 pandemic. J. Environ. Manag. 2021, 286, 112140. [CrossRef]

107. World Health Organization (WHO). Water, Sanitation, Hygiene, and Waste Management for the COVID-19 Virus: Interim Guidance. 2020. Available online: https:/ / apps.who.int/iris/handle/10665/331499 (accessed on 29 October 2021).

108. Rutala, W.A.; Mayhall, G. Medical waste. Infect. Control Hosp. Epidemiol. 1992, 13, 38-48. [CrossRef]

109. Ozbay, G.; Jones, M.; Gadde, M.; Isah, S.; Attarwala, T. Design and Operation of Effective Landfills with Minimal Effects on the Environment and Human Health. J. Environ. Public Health 2021, 2021, 6921607. [CrossRef]

110. Hereher, M.E.; Al-Awadhi, T.; Mansour, S.A. Assessment of the optimized sanitary landfill sites in Muscat, Oman. Egypt. J. Remote Sens. 2020, 23, 355-362. [CrossRef]

111. Nik Ab Rahim, N.N.; Othman, J.; Hanim Mohd Salleh, N.; Chamhuri, N. A Non-Market Valuation Approach to Environmental Cost-Benefit Analysis for Sanitary Landfill Project Appraisal. Sustainability 2021, 13, 7718. [CrossRef]

112. Kareem, S.L.; Al-Mamoori, S.K.; Al-Maliki, L.A.; Al-Dulaimi, M.Q.; Al-Ansari, N. Optimum location for landfills landfill site selection using GIS technique: Al-Naja city as a case study. Cogent Eng. 2021, 8, 1863171. [CrossRef]

113. Diaz, L.F.; Savage, G.M.; Eggerth, L.L. Alternatives for the treatment and disposal of healthcare wastes in developing countries. Waste Manag. 2005, 25, 626-637. [CrossRef]

114. Ilyas, S.; Srivastava, R.R.; Kim, H. Disinfection technology and strategies for COVID-19 hospital and bio-medical waste management. Sci. Total Environ. 2020, 749, 141652. [CrossRef]

115. Datta, P.; Mohi, G.K.; Chander, J. Biomedical waste management in India: Critical appraisal. J. Lab. Phys. 2018, 10, 6-14. [CrossRef]

116. Wang, J.; Shen, J.; Ye, D.; Yan, X.; Zhang, Y.; Yang, W.; Li, X.; Wang, J.; Zhang, L.; Pan, L. Disinfection technology of hospital wastes and wastewater: Suggestions for disinfection strategy during coronavirus disease 2019 (COVID-19) pandemic in China. Environ. Pollut. 2020, 262, 114665. [CrossRef]

117. Karagiannidis, A.; Papageorgiou, A.; Perkoulidis, G.; Sanida, G.; Samaras, P. A multi-criteria assessment of scenarios on thermal processing of infectious hospital wastes: A case study for Central Macedonia. Waste Manag. 2010, 30, 251-262. [CrossRef]

118. Voudrias, E.A. Technology selection for infectious medical waste treatment using the analytic hierarchy process. J. Air Waste Manag. Assoc. 2016, 66, 663-672. [CrossRef]

119. Voudrias, E.; Graikos, A. Infectious Medical Waste Management System at the Regional Level. J. Hazard. Toxic Radioact. Waste 2014, 18, 04014020. [CrossRef]

120. Lee, C.C.; Huffman, G.L. Review: Medical waste management/incineration. J. Hazard. Mater. 1996, 48, 1-30. [CrossRef]

121. Schecter, A.; Birnbaum, L.; Ryan, J.J.; Constable, J.D. Dioxins: An overview. Environ. Res. 2006, 101, 419-428. [CrossRef]

122. Pacyna, E.G.; Pacyna, J.M.; Steenhuisen, F.; Wilson, S. Global anthropogenic mercury emission inventory for 2000. Atmos. Environ. 2006, 40, 4048-4063. [CrossRef]

123. Wolfe, M.F.; Schwarzbach, S.; Sulaiman, R.A. Effects of mercury on wildlife: A comprehensive review. Environ. Toxicol. Chem. 1998, 2, 146-160. [CrossRef]

124. Kilgroe, J.D. Control of dioxin, furan, and mercury emissions from municipal waste combustors. J. Hazard. Mater. 1996, 47, 163-194. [CrossRef]

125. Xu, L.; Dong, K.; Zhang, Y.; Li, H. Comparison and analysis of several medical waste treatment technologies. IOP Conf. Ser. Earth Environ. Sci. 2020, 615, 012031. [CrossRef]

126. Dharmaraj, S.; Ashokkumar, V.; Pandiyan, R.; Halimatul Munawaroh, H.S.; Chew, K.W.; Chen, W.H.; Ngamcharussrivichai, C. Pyrolysis: An effective technique for degradation of COVID-19 medical wastes. Chemosphere 2021, 275, 130092. [CrossRef]

127. Czajczyńska, D.; Anguilano, L.; Ghazal, H.; Krzyżyńska, R.; Reynolds, A.J.; Spencer, N.; Jouhara, H. Potential of pyrolysis processes in the waste management sector. Therm. Sci. Eng. Prog. 2017, 3, 171-197. [CrossRef] 
128. Khaskhachikh, V.V.; Kornil'eva, V.F.; Gerasimov, G.Y. Investigation into the Pyrolysis of Medical Waste in a Fixed-Bed Reactor. J. Eng. Phys. Thermophys. 2021, 94, 580-586. [CrossRef]

129. Zimmermann, K. Microwave as an emerging technology for the treatment of biohazardous waste: A mini-review. Waste Manag. Res. 2017, 35, 471-479. [CrossRef]

130. Mantzaras, G.; Voudrias, E.A. An optimization model for collection, haul, transfer, treatment and disposal of infectious medical waste: Application to a Greek region. Waste Manag. 2017, 69, 518-534. [CrossRef] [PubMed]

131. Duarte, P.; Santana, V.T. Disinfection measures and control of SARS-COV-2 transmission. Glob. Biosecur. 2020, 2. [CrossRef]

132. Cai, X.; Du, C. Thermal Plasma Treatment of Medical Waste. Plasma Chem. Plasma Process. 2021, 41, 1-46. [CrossRef]

133. Aboughaly, M.; Gabbar, H.A.; Damideh, V.; Hassen, I. RF-ICP Thermal Plasma for Thermoplastic Waste Pyrolysis Process with High Conversion Yield and Tar Elimination. Processes 2020, 8, 281. [CrossRef]

134. Erdogan, A.A.; Yilmazoglu, M.Z. Plasma gasification of the medical waste. Int. J. Hydrogen Energy 2021, 46, $29108-29125$. [CrossRef] [PubMed]

135. Cahyanti, M.N.; Doddapaneni, T.R.K.C.; Kikas, T. Biomass torrefaction: An overview on process parameters, economic and environmental aspects and recent advancements. Bioresour. Technol. 2020, 301, 122737. [CrossRef]

136. Giakoumakis, G.E.; Sidiras, D.K. Torrefaction for Increasing Gross Heat of Combustion of Medical Cotton Waste. Int. J. Econ. Manag. Strategy 2017, 2, 350-355. Available online: https:/ / www.iaras.org/iaras/filedownloads/ijems/2017/007-0049(2017).pdf (accessed on 31 October 2021).

137. Giakoumakis, G.; Politi, D.V.; Sidiras, D.K. Torrefied medical cotton waste for industrial liquid waste cleaning. In Proceedings of the European Biomass Conference and Exhibition Proceedings, 2018 (26th EUBCE), Copenhagen, Denmark, 14-18 May 2018; pp. 1429-1433.

138. Kale, R.D.; Gorade, V.G.; Parmaj, O. Waste Medical Cotton Reinforced Chitosan Biocomposite Film Using Tannic Acid as the Crosslinking Agent. J. Nat. Fibers 2018, 17, 1249-1256. [CrossRef]

139. Emam, H.E.; Saleh, N.H.; Nagy, K.S.; Zahran, M.K. Functionalization of medical cotton by direct incorporation of silver nanoparticles. Int. J. Biol. Macromol. 2015, 78, 249-256. [CrossRef]

140. Sheriteh, Z.; Hassan, T.; Sherriff, M.; Cobourne, M. Decontamination procedures for tungsten carbide debonding burs: A cross-sectional survey of hospital-based orthodontic departments. J. Orthod. 2010, 37, 174-180. [CrossRef]

141. Sajjanshetty, S.; Hugar, D.; Hugar, S.; Ranjan, S.; Kadani, M. Decontamination Methods Used for Dental Burs-A Comparative Study. J. Clin. Diagn. Res. 2014, 8, 39-41. [CrossRef]

142. Chen, H. Lignocellulose biorefinery feedstock engineering. In Lignocellulose Biorefinery Engineering, 1st ed.; Elsevier: Amsterdam, The Netherlands, 2015; pp. 37-86. [CrossRef]

143. Giakoumakis, G.; Sidiras, D. Acid Hydrolysis Pretreated Recycled Medical Cotton Waste as Heating Energy Material. In Proceedings of the 27th European Biomass Conference and Exhibition, Lisbon, Portugal, 27-30 May 2019; pp. $1213-1217$.

144. Giakoumakis, G.; Sidiras, D. Acid Hydrolyzed Medical Cotton Waste as a Methylene Blue Low-Cost Adsorbent. In Proceedings of the 28th European Biomass Conference and Exhibition, e-EUBCE 2020, Marseille, France, 6-9 July 2020; pp. 660-664.

145. Giakoumakis, G.; Karnaouri, A.; Topakas, E.; Sidiras, D. Simulation and optimization of combined acid pretreatment and enzymatic saccharification of medical cotton waste. Biomass Convers. Biorefin. 2021, 11, 515-526. [CrossRef]

146. Sun, Y.; Cheng, J. Hydrolysis of lignocellulosic materials for ethanol production: A review. Bioresour. Technol. 2002, 83, 1-11. [CrossRef]

147. Dimos, K.; Paschos, T.; LouLoudi, A.; Kalogiannis, K.; Lappas, A.A.; Papayannakos, N.; Kekos, D. Effect of various pretreatment methods on bioethanol production from cotton stalks. Fermentation 2019, 5, 5. [CrossRef]

148. Andrić, P.; Meyer, A.S.; Jensen, P.A.; Dam-Johansen, K. Reactor design for minimizing product inhibition during enzymatic lignocellulose hydrolysis: I. Significance and mechanism of cellobiose and glucose inhibition on cellulolytic enzymes. Biotechnol. Adv. 2010, 28, 308-324. [CrossRef]

149. Duff, S.J.B.; Murray, W.D. Bioconversion of forest products industry waste cellulosics to fuel ethanol: A review. Bioresour. Technol. 1996, 55, 1-33. [CrossRef]

150. Yang, B.; Dai, Z.; Ding, S.Y.; Wyman, C.E. Enzymatic hydrolysis of cellulosic biomass. Biofuels 2011, 2, 421-449. [CrossRef]

151. Cheung, S.W.; Anderson, B.C. Laboratory investigation of ethanol production from municipal primary wastewater solids. Bioresour. Technol. 1997, 59, 81-96. [CrossRef]

152. Vignesh, N.; Chandraraj, K. Improved high solids loading enzymatic hydrolysis and fermentation of cotton microdust by surfactant addition and optimization of pretreatment. Process Biochem. 2021, 106, 60-69. [CrossRef]

153. Rasul, S.B.; Som, U.; Hossain, M.S.; Rahman, M. Liquid fuel oil produced from plastic based medical wastes by thermal cracking. Sci. Rep. 2021, 11, 17048. [CrossRef]

154. Som, U.; Rahman, F.; Hossain, S. Recovery of Pyrolytic Oil from Thermal Pyrolysis of Medical Waste. J. Eng. Sci. 2018, 5, H5-H8. [CrossRef]

155. Shen, Y.; Yu, S.; Ge, S.; Chen, X.; Ge, X.; Chen, M. Hydrothermal carbonization of medical wastes and lignocellulosic biomass for solid fuel production from lab-scale to pilot-scale. Energy 2017, 118, 312-323. [CrossRef]

156. Fang, S.; Jiang, L.; Li, P.; Bai, J.; Chang, C. Study on pyrolysis products characteristics of medical waste and fractional condensation of the pyrolysis oil. Energy 2020, 195, 16969. [CrossRef] 
157. Xin, S.; Huang, F.; Liu, X.; Mi, T.; Xu, Q. Torrefaction of herbal medicine wastes: Characterization of the physicochemical properties and combustion behaviors. Bioresour. Technol. 2019, 287, 121408. [CrossRef]

158. Li, X.; Xu, Q.; Shen, H.; Guo, Y.; Wu, M.; Peng, Y.; Zhang, L.; Zhao, Z.K.; Liu, Y.; Xie, H. Capturing $\mathrm{CO}_{2}$ to reversible ionic liquids for dissolution pretreatment of cellulose towards enhanced enzymatic hydrolysis. Carbohydr. Polym. 2019, 204, 50-58. [CrossRef]

159. Gan, J.; Peng, Y. Reversible covalent chemistry of carbon dioxide unlocks the recalcitrance of cellulose for its enzymatic saccharification. Bioresour. Technol. 2020, 295, 22230. [CrossRef]

160. Dash, A.; Kumar, S.; Singh, R.K. Thermolysis of Medical Waste (Waste Syringe) to Liquid Fuel Using Semi Batch Reactor. Waste Biomass Valor 2015, 6, 507-514. [CrossRef]

161. Baghdadi, M.; Alipour Soltani, B.; Nourani, M. Malachite green removal from aqueous solutions using fibrous cellulose sulfate prepared from medical cotton waste: Comprehensive batch and column studies. J. Ind. Eng. Chem. 2017, 55, 128-139. [CrossRef]

162. Mohseni-Bandpei, A.; Majlesi, M.; Rafiee, M.; Nojavan, S.; Nowrouz, P.; Zolfagharpour, H. Polycyclic aromatic hydrocarbons (PAHs) formation during the fast pyrolysis of hazardous health-care waste. Chemosphere 2019, 227, 277-288. [CrossRef]

163. Ismail, Z.Z.; Talib, A.R. Recycled medical cotton industry waste as a source of biogas recovery. J. Clean. Prod. 2016, 112, 4413-4418. [CrossRef]

164. Arcuri, C.; Luciani, F.; Piva, P.; Bartuli, F.; Ottria, L.; Mecheri, B.; Licoccia, S. Medical waste to energy: Experimental study. Oral Implantol. 2014, 6, 83-88. [CrossRef]

165. Alam, M.T.; Lee, J.-S.; Lee, S.Y.; Bhatta, D.; Yoshikawa, K.; Seo, Y.-C. Low Chlorine Fuel Pellets Production from the Mixture of Hydrothermally Treated Hospital Solid Waste, Pyrolytic Plastic Waste Residue and Biomass. Energies 2019, 12, 4390. [CrossRef]

166. Manegdeg, F.; Coronado, L.O.; Paña, R. Medical waste treatment and electricity generation using pyrolyzer-rankine cycle for specialty hospitals in Quezon City, Philippines. IOP Conf. Ser. Earth Environ. Sci. 2020, 463, 012180. [CrossRef]

167. Bujak, J. Thermal treatment of medical waste in a rotary kiln. J. Environ. Manag. 2015, 162, 139-147. [CrossRef]

168. Bujak, J. Experimental study of the energy efficiency of an incinerator for medical waste. Appl. Energy 2009, 86, 2386-2393. [CrossRef]

169. Bujak, J.W. Heat recovery from thermal treatment of medical waste. Energy 2015, 90, 1721-1732. [CrossRef]

170. Świechowski, K.; Leśniak, M.; Białowiec, A. Medical Peat Waste Upcycling to Carbonized Solid Fuel in the Torrefaction Process. Energies 2021, 14, 6053. [CrossRef]

171. Chaiyat, N. Energy, exergy, economic, and environmental analysis of an organic Rankine cycle integrating with infectious medical waste incinerator. Therm. Sci. Eng. Prog. 2021, 22, 100810. [CrossRef]

172. Zroychikov, N.A.; Fadeev, S.A.; Bezruky, P.P. Development of an Environmentally Safe Process for Medical Waste Disposal Based on Pyrolysis. Therm. Eng. 2018, 65, 833-840. [CrossRef]

173. Álvarez, A.M. Analysis of the Thermal Treatment of Plastic Medical Waste. Master's Thesis, Comillas Pontifical University, Madrid, Spain, 2018. Available online: https://repositorio.comillas.edu/rest/bitstreams/143601/retrieve (accessed on 16 November 2021).

174. Llewellyn, K. Incineration, Waste-to-Energy and Catalytic Gasification: The Past, Present and Future of Medical Waste Management. Master's Thesis, Columbia University, New York, NY, USA, 2006. Available online: https://gwcouncil.org/wp-content/ uploads /2020/10/llewellyn_thesis.pdf (accessed on 15 November 2021).

175. Ökten, H.E.; Corum, A.; Demir, H.H. A comparative economic analysis for medical waste treatment options. Environ. Prot. Eng. 2015, 41, 138-145. [CrossRef]

176. Soares, S.R.; Rodrigues, A.F.; Prudêncio da Silva, V.; Rodrigo, A.F. Applications of life cycle assessment and cost analysis in health care waste management. Waste Manag. 2013, 33, 175-183. [CrossRef] [PubMed]

177. Kargar, S.; Pourmehdi, M.; Paydar, M.M. Reverse logistics network design for medical waste management in the epidemic outbreak of the novel coronavirus (COVID-19). Sci. Total. Environ. 2020, 746, 141183. [CrossRef] [PubMed]

178. Liu, Z.; Liu, T.; Liu, X.; Wei, A.; Wang, X.; Yin, Y.; Li, Y. Research on Optimization of Healthcare Waste Management System Based on Green Governance Principle in the COVID 19 Pandemic. Int. J. Environ. Res. Public Health 2021, 18, 5316. [CrossRef] [PubMed]

179. Torkayesh, A.E.; Vandchali, H.R.; Tirkolaee, E.B. Multi-Objective Optimization for Healthcare Waste Management Network Design with Sustainability Perspective. Sustainability 2021, 13, 8279. [CrossRef]

180. Ghannadpour, S.F.; Zandieh, F.; Esmaeili, F. Optimizing triple bottom-line objectives for sustainable health-care waste collection and routing by a self-adaptive evolutionary algorithm: A case study from tehran province in Iran. J. Clean. Prod. 2021, 287, 125010. [CrossRef]

181. Rolewicz-Kalińska, A. Logistic Constraints as a Part of a Sustainable Medical Waste Management System. Transp. Res. Proc. 2016, 16, 473-482. [CrossRef]

182. Van Straten, B.; Dankelman, J.; Van der Eijk, A.; Horeman, T. A Circular Healthcare Economy; a feasibility study to reduce surgical stainless steel waste. Sustain. Prod. Consum. 2021, 27, 169-175. [CrossRef]

183. Yao, L.; Xu, Z.; Zeng, Z. A Soft-Path Solution to Risk Reduction by Modeling Medical Waste Disposal Center Location-Allocation Optimization. Risk Anal. 2020, 40, 1863-1886. [CrossRef]

184. Arun, K.P.; Wang, S.J. The Design Intervention Opportunities to Reduce Procedural-Caused Healthcare Waste Under the Industry 4.0 Context-A Scoping Review. In Interactivity and Game Creation; Brooks, A., Brooks, E.I., Jonathan, D., Eds.; Lecture Notes of the Institute for Computer Sciences, Social Informatics and Telecommunications Engineering; Springer: Cham, Switzerland, 2021; Volume 367. [CrossRef] 
185. Ranjbari, M.; Esfandabadi, Z.S.; Shevchenko, T.; Chassagnon-Haned, N.; Peng, W.; Tabatabaei, M.; Aghbashlo, M. Mapping healthcare waste management research: Past evolution, current challenges, and future perspectives towards a circular economy transition. J. Hazard. Mater. 2022, 422, 126724. [CrossRef]

186. Chaerul, M.; Tanaka, M.; Shekdar, A.V. Resolving complexities in healthcare waste management: A goal programming approach. Waste Manag. Res. 2008, 26, 217-232. [CrossRef]

187. Nursetyowati, P.; Nadifameidita, F.Q.; Fairus, S.; Surya Irawan, D.; Rohajawati, S. Optimization of medical hazardous waste management in community health centers of depok city using analytical hierarchy process (AHP) method. J. Phys. Conf. Ser. 2019, 1364, 012040. [CrossRef]

188. Mei, X.; Hao, H.; Sun, Y.; Wang, X.; Zhou, Y. Optimization of medical waste recycling network considering disposal capacity bottlenecks under a novel coronavirus pneumonia outbreak. Environ. Sci. Pollut. Res. Int. 2021, 1-19. [CrossRef] 